\title{
Assessment of the representation of Antarctic Bottom Water properties in the ECCO2 reanalysis
}

\author{
M. Azaneu, R. Kerr, and M. M. Mata \\ Laboratório de Estudos dos Oceanos e Clima, Instituto de Oceanografia, Universidade Federal do Rio Grande (FURG), \\ Rio Grande, RS, 96203-900, Brazil \\ Correspondence to: M. Azaneu (m.azaneu@furg.br)
}

Received: 19 February 2014 - Published in Ocean Sci. Discuss.: 28 March 2014

Revised: 29 September 2014 - Accepted: 17 October 2014 - Published: 21 November 2014

\begin{abstract}
We analyzed the ability of the Estimating the Circulation and Climate of the Ocean - Phase II (ECCO2) reanalysis to represent the hydrographic properties and variability of Antarctic Bottom Water (AABW) in the Southern Ocean. We used a 20-year (1992-2011) observational database to perform comparisons of hydrographic properties and reanalysis output for the same time period. Four case studies based on current meter data and the AABW volume transport estimates previously reported in the literature were also evaluated. The opening and maintenance of an oceanic polynya in the Weddell Sea sector is observed after 2004 in the reanalysis product. Moreover, intense deep water production due to deep convection occurs, which leads to a scenario in which the Weddell Sea is flooded with AABW. For this reason, our analyses focused on the period that was identified as more reliable (1992-2004). The main Southern Ocean oceanographic features, as well as the characteristic shape of the regional potential temperature-salinity $(\theta-S)$ diagrams, are coincident with observations. However, the reanalysis output produces surface waters that are generally denser than observations due to the reproduction of waters that are generally saltier than expected, which probably resulted from the strong seasonality of sea ice concentrations. Bottom waters are warmer and less dense, while intermediate waters are statistically closest to the observations. The differences in bottom water properties are partially due to the inability of the reanalysis to properly reproduce the formation and export of dense waters from the shelf and the consequent absence of the densest AABW variety for most of the analyzed period. Despite differences in the absolute values, the upper AABW limit $\left(\gamma^{\mathrm{n}} \geq 28.27 \mathrm{~kg} \mathrm{~m}^{-3}\right)$ and AABW occupied area estimates are coincident with the observations
\end{abstract}

in the World Ocean Circulation Experiment (WOCE) repeat sections SR2 and SR4. Moreover, the AABW volume export and current velocity variability are correlated with the observed time series in the most important region of dense water export (i.e., the Weddell Sea). Despite the consistency in terms of variability, the absolute volume transport and velocity estimates are underrepresented in all cases.

\section{Introduction}

Antarctic Bottom Water (AABW) covers ca. $58 \%$ of the ocean's abyssal layer and fills and ventilates the deepest basins of the global ocean (Johnson, 2008). Dense bottom water formation and spread, which occur mainly in deep western boundary currents, are important physical processes that contribute to the variability of the global overturning circulation deep cell (Talley, 2013). The meridional overturning circulation cells are the main mechanisms that are responsible for the interbasin exchange of mass, heat, salt, carbon, and nutrients; therefore, these cells contribute substantially to global climate regulation (e.g., Rahmstorf, 2006; Lumpkin and Speer, 2007).

The AABW formation occurs regionally around the Antarctic margin through the mixing of intermediate waters with near-freezing point shelf waters (e.g., Carmack and Foster, 1975; Foldvik et al., 1985; Nicholls et al., 2009). The latter results from shelf waters that are modified by atmospheric interaction and brine rejection during sea ice production and also by cooling through basal contact with floating ice shelves. The Weddell Sea is considered the main contributor to the AABW formation (Rintoul, 1998; Orsi et al., 1999). 
The Weddell Sea Bottom Water (WSBW) is the densest local AABW variety within the Weddell Sea and is mostly confined to the Weddell Basin (Orsi et al., 1993). The Weddell Sea Deep Water (WSDW) overlies the WSBW and is light enough to spread into the global ocean through the narrow passages of the South Scotia Ridge (Muench and Hellmer, 2002; Franco et al., 2007). The WSDW can be formed either directly by entrainment during the downslope flow of dense plumes from the shelf or by mixing of the WSBW with Warm Deep Water (WDW; Orsi et al., 1993, 1999; Meredith et al., 2000). Occasionally, bottom water formation can occur in the open ocean region through deep convection, such as occurred with the Weddell Polynya events observed during the successive winters of 1974-1976 (Gordon, 1977). During this process, there is an intense heat loss to the atmosphere, which decreases vertical stability and allows open ocean deep convection to depths much greater than usual (Killworth, 1983).

The dominant characteristics of regional AABW varieties depend on the local type of shelf water and on complex local physical processes that are coupled and related to sea ice formation, such as the opening of coastal polynyas, ice shelf basal melting, and mixing with overlying waters (Gill, 1973; Carmack and Foster, 1975; Foldvik et al., 1985; Orsi et al., 1999; Nicholls et al., 2009). The Antarctic sea ice area undergoes a large seasonal cycle, varying in extent by approximately $83 \%$ (Parkinson and Cavalieri, 2012). In the summer, freshwater from ice melt plays a key role in the modification of Antarctic Surface Waters (AASW), whereas brine rejection in winter resulting from sea ice formation enhances shelf water salinity and contributes to dense water formation.

Several studies have reported changes in the hydrographic properties of the AABW source waters during recent decades. These changes include freshening of dense waters in the Weddell and Ross Seas shelf regions (e.g., Jacobs et al., 2002; Jacobs and Giulivi, 2010; Jacobs, 2004; Hellmer et al., 2011; Azaneu et al., 2013). In addition, long-term warming was observed for the intermediate waters of the Antarctic Circumpolar Current (ACC; during the 1990s; Gille, 2002) and WDW within the Weddell Gyre (1970s-1990s, Robertson et al., 2002). In turn, properties of the AABW recently formed have also changed over the years. The WSBW in the inner Weddell Sea and the Prime Meridian experienced warming during the second half of the 1990s (0.01 and $0.003{ }^{\circ} \mathrm{C} \mathrm{yr}^{-1}$, respectively; Fahrbach et al., 2004). A more extended study reported a WSDW and WSBW temperature and salinity increase (1998-2008) after a decreasing period in 1984-1992 (Fahrbach et al., 2011). Abyssal waters in the Australian-Antarctic Basin and Princess Elizabeth Trough experienced warming $\left(0.1\right.$ and $\left.0.05^{\circ} \mathrm{C}\right)$ and freshening $(-0.005$ and -0.01$)$ between 1994/1995 and 2007 (Johnson et al., 2008). Moreover, freshening has been observed in the AABW within the Indian and Pacific sectors of the Southern Ocean (1995-2005; Rintoul, 2007). Freshening of the deep Amundsen-Bellingshausen, Australian-Antarctic and Weddell Basins between 1991 and 2008 was also identified in World Ocean Circulation Experiment (WOCE) data; the latter basin exhibited the smallest trend (Purkey and Johnson, 2013). The contraction of the AABW was reported by Purkey and Johnson (2010) during the 1990s-2000s. Azaneu et al. (2013) also observed a reduction in the volume, as well as warming and a density decrease, in the AABW during the past 50 years (1958-2011). Consistent with these findings, a decrease in the WSBW contributions $(\sim 20 \%)$ to the total water mass mixture in the Weddell Basin was identified during the 1980s-1990s (Kerr et al., 2009). Reduced AABW volume can result from changes in the properties of the produced dense water or from a decrease in its formation rate. The latter can be one of the factors linked to the aging and reduced ventilation rate of WSBW and WSDW at the Prime Meridian between 1984 and 2011 (15 and $21 \%$ reductions in the ventilation rates, respectively); larger reductions in the ventilation rates of WSBW near the bottom water sources (26-30\%) occurred during the period 1992-2011 (Huhn et al., 2013).

Despite the possible global implications of these longterm changes, the limited and summer-biased sampling in the Southern Ocean precludes a better understanding of the connections between these processes and the embedded physical mechanisms. Assimilation of data into ocean models offers a potentially useful tool to fill the information gaps of observational data in terms of spatial and temporal resolution by providing a more synoptic and holistic view of the main processes acting on observed changes. However, the capability and consistency of these products still need to be evaluated and investigated (Dotto et al., 2014), particularly for the deep Southern Ocean, where the available in situ data set is still sparse in both time and space (e.g., Rintoul et al., 2012).

Our study aims to perform a detailed evaluation of the representation of hydrographic properties and the variability of the AABW in the Southern Ocean from the Estimating the Circulation and Climate of the Ocean - Phase II (ECCO2) reanalysis output. Over the past decade, several global ocean data assimilation products have been developed based on the synthesis of observations through the physics described by global ocean general circulation models (Lee et al., 2010). The original ECCO project was established in 1998 as part of the WOCE, with the intent of generating a quantitative reproduction of the time-evolution of ocean states (Menemenlis et al., 2008); this project has focused on decadal and long-term climate changes (Wunsch et al., 2009). For example, Wunsch and Hemibach (2014) used an updated ECCO product to describe temperature and heat content changes primarily in the abyssal ocean. The authors found a linearly decreasing trend in the integrated global heat content below $2000 \mathrm{~m}$. Moreover, they also found an important regional heterogeneity that was most evident with respect to a warming in the western Atlantic and sectors of the deep Southern Ocean. However, previous ECCO solutions were limited by the coarse resolution and absence of sea ice representation. Thus, the ECCO2 was created to improve these 
deficiencies by producing a global eddy-permitting solution that includes sea ice. ECCO2 presents dynamically consistent simulations because it is generated by a model that is forward run using optimized values of control parameters (Menemenlis et al., 2008). Therefore, the reanalysis product ECCO2 presents itself as a potentially valuable tool for ocean variability and long-term change studies, emphasizing that the assessment of the ECCO2 reanalysis products based on their reproduction of the properties and variability of such climate-impacting water masses as the AABW is fundamental for ensuring the future use of these data with respect to the Southern Ocean hydrography and decadal variability. In Sect. 2, we describe ECCO2 in greater detail and present the observational data used for comparison. We also describe in detail how we compared the distinct data sets, aiming to investigate the representation of AABW hydrographic properties, ocean current velocity and transport, and dense water variability. The comparison results are presented in Sect. 3, in which we first evaluate the climatological representation of hydrographic data over ocean layers (Sect. 3.1) and along hydrographic sections (Sect. 3.2). Velocity and transport are evaluated in Sect. 3.3 based on four case studies. In Sect. 3.4, the long-term variability of AABW properties is determined Finally, a general discussion, comparison with other studies and final considerations are presented in Sect. 4.

\section{Data and methods}

\subsection{ECCO2 reanalysis product}

The ECCO2 data synthesis is based on a global full-depth ocean and sea ice configuration from the Massachusetts Institute of Technology general circulation model (MITgcm; Marshall et al., 1997). The model configuration for this product has a cube-sphere grid with a global horizontal grid spacing of $18 \times 18 \mathrm{~km}$ and 50 vertical levels ranging from $10 \mathrm{~m}$ thick near the surface to approximately $450 \mathrm{~m}$ thick at the deepest level. The model resolution is eddy-permitting at higher latitudes. The ocean global circulation model is coupled to a sea ice model that computes sea ice thickness, sea ice concentration, and snow cover, which allows the system to be constrained by polar satellite observations (Zhang et al., 1998). A Green's function approach is used to adjust the control parameters by reducing the model-data misfit (Menemenlis et al., 2005). The data constraints include sea level anomalies from altimeter data; time-mean sea levels from Maximenko and Niiler (2005); sea surface temperatures from the Group for High Resolution Sea Surface Temperature; temperature and salinity profiles, including the WOCE, TAO, Argo, and XBT; sea ice concentration from passive microwave data; sea ice motion from radiometers, QuikSCAT, and RADARSAT Geophysical Processing System; and sea ice thickness from Upward Looking Sonar (Menemenlis et al., 2008).
The ECCO2 reanalysis products have been used for several scientific applications, such as studying the effect of extreme North Atlantic Oscillation forcing the freshwater budget in the Arctic (Condron et al., 2009) and formation of the upper Arctic halocline (Nguyen et al., 2009). Using a regional configuration with a high-resolution $(4 \mathrm{~km}$ horizontal) grid, Rignot et al. (2012) examined the spreading pattern of warm subtropical-origin waters around Greenland in 1992-2009 and observed warming of subsurface waters in the subpolar gyre. In the Southern Ocean, the ECCO 2 reanalysis was used to evaluate meridional heat transport mechanisms (Volkov et al., 2010). Mazloff et al. (2010) developed a preliminary solution with a 1/6-degree resolution for the Southern Ocean by applying an adjoint-based state estimation on a regional scale for the 2005-2010 period (Southern Ocean State Estimate - SOSE). More recently, the analysis of Lagrangian trajectories was applied to this high-resolution product to show that the pathways of the different sources of AABW amalgamate into one pathway even before they reach $31^{\circ} \mathrm{S}$ in the deep subtropical basins (van Sebille et al., 2013).

In this work, we used the solution "cube 92" (version identifier) with a 0.25 degree regular latitude-longitude grid. The surface forcing of this solution is provided by the Japan Meteorological Agency and Central Research Institute of Electric Power Industry 25-year reanalysis (JRA-25; Onogi et al., 2007). The data used in this study span from 1992 to 2011 and cover the geographic area south of $60^{\circ} \mathrm{S}$. The parameters evaluated were monthly fields of potential temperature $(\theta)$, salinity $(S)$, and the ocean current zonal $(u)$ and meridional $(v)$ velocity components as well as daily surface wind stress, sea ice thickness, and ice-covered area-percent data. Computed neutral density fields $\left(\gamma^{\mathrm{n}}\right.$; Jackett and McDougall, 1997) were used for water masses definitions.

\subsection{Observational data sets}

\subsubsection{Hydrographic data set used for reanalysis assessment}

The observational data set used here was compiled from data sets of the World Ocean Database 2009, 1958-2011 (WOD09, Boyer et al., 2009); the Alfred Wegener Institute, 2003-2010; and the Brazilian High Latitude Oceanography Group (GOAL; www.goal.furg.br) CTD data, 2003-2011. More details about the data set can be found in Azaneu et al. (2013). The combined data set covers waters south of $60^{\circ} \mathrm{S}$ over a 54-year period (1958-2011) (Fig. 1).

Three WOCE repeat hydrographic sections (i.e., SR2, SR3, and SR4; Fig. 1) were selected to evaluate the entire ECCO2 water column representation in the Southern Ocean. The western part of section WOCE SR4 is located in the main outflow route of the AABW export (e.g., Naveira Garabato et al., 2002; Kerr et al., 2012), whereas the WOCE SR2/A12 (South Africa to Antarctica) section refers to the recirculation flow of the AABW within the Weddell Gyre (e.g., 


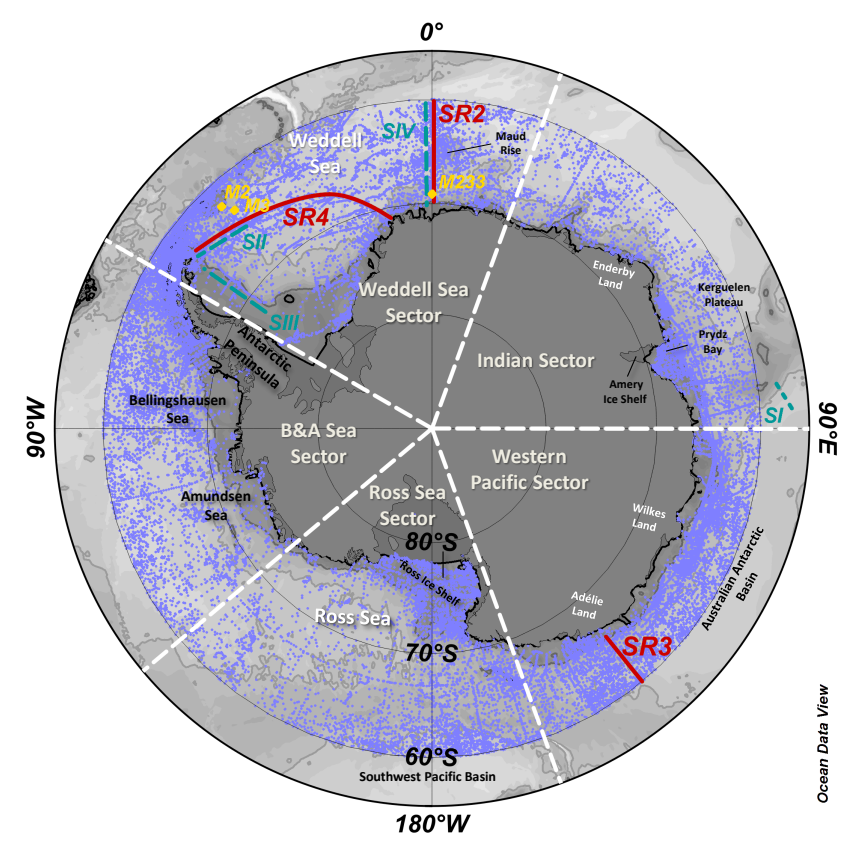

Figure 1. Map indicating the geographic areas of oceanographic profiles (blue dots), hydrographic sections, and mooring positions used in this study. Mooring positions from Klatt et al. (2005) (M233) and Gordon et al. (2010) (M2 and M3) are indicated by yellow diamonds. Sections where volume transport was determined (Section I - SI, Section II - SII, Section III - SIII, and Section IV - SIV) are indicated by green dashed lines. Red lines denote the repeat WOCE hydrographic sections used in this study (sampling periods are presented in Table S1 - see Supplement). Dark and light gray lines refer to the bathymetry of 1300 and $4000 \mathrm{~m}$, respectively. The radiating white boundary lines delineate hydrographic sectors. B\&A denotes the Bellingshausen and Amundsen Sea sector.

Klatt et al., 2005). The cross-slope section (i.e., WOCE SR3) is located in the Australian-Antarctic Basin and crosses the AABW westward flow away from its main regional sources (Ross Sea, Adelie and George V Land regions; Rintoul, 1998; Shimada et al., 2012). The cross-sections WOCE SR2 and WOCE SR3 are limited to south of $60^{\circ} \mathrm{S}$ in this study. Those sections were defined because of the availability of historical data in close proximity; the historical data were used to maximize the number of observations. In addition, those specific occupations occurred during the time coverage of the ECCO2 simulation, providing a synoptic comparison.

The ocean current velocity data from previous studies were used for comparison in specific case studies. The data from moorings M2/M3 within the Weddell Sea (Fig. 1; Gordon et al., 2010) and moorings M233/M229 (Fig. 1; Klatt et al., 2005) along the Prime Meridian were compared with the ECCO2 product. Time series of the cross-section of the AABW volume transport for the northwestern Weddell Sea (from Fahrbach et al. (2001) and Kerr et al. (2012); Section II in Fig. 1) and east of the Kerguelen plateau (from Fukamachi et al. (2010); Section I in Fig. 1) were also used for compari- son with the ECCO2 estimates. The case studies are summarized in Table 1.

\subsubsection{Sea ice data}

The monthly sea ice concentration data set from the National Snow and Ice Data Center was based on brightness temperature measurements derived from several passive microwave instruments (Nimbus-7 Scanning Multichannel Microwave Radiometer; the Defense Meteorological Satellite Program (DMSP) F8, F11, and F13 Special Sensor Microwave/Imagers; and the DMSP-F17 Special Sensor Microwave Imager/Sounder; NSIDC; Cavalieri et al., 2006). The data were generated using the NASA Team algorithm developed by the Oceans and Ice Branch, Laboratory for Hydrospheric Processes at the NASA Goddard Space Flight Center. Sea ice concentration data refer to the percentage of pixel area $(25 \times 25 \mathrm{~km})$ covered by ice and spans from October 1978 to December 2010. In this work, we only used data concurrent with the ECCO2 reanalysis period (1992-2010).

A monthly time series of sea ice-covered area percentages was determined based on the average percentage of pixels over the Southern Ocean. Pixels showing less than $15 \%$ covered area were not considered to be covered by ice (Cavalieri et al., 2006).

\subsection{AABW definition}

Our assessments are focused on the representation of the AABW, defined here as Southern Ocean waters denser than $\gamma^{\mathrm{n}}=28.27 \mathrm{~kg} \mathrm{~m}^{-3}$. We have not considered dense shelf waters, which are limited by the $1300 \mathrm{~m}$ isobath. This definition based on neutral density surface includes all the several varieties of the AABW produced around the Southern Ocean continental margins (e.g., Whitworth et al., 1998) and exported to the world ocean (as described by Orsi et al., 1999). This density-based definition of the AABW was recently applied in a model-based investigation of the AABW production and export (Kerr et al., 2012) and also in an analysis of long-term AABW hydrographic property variability (Azaneu et al., 2013). The choice and use of this robust definition for the AABW limit throughout the Antarctic continent are important for previous and future comparisons, even when considering only evaluations among observations and/or between model results and observations. The isolines of $\theta=0^{\circ} \mathrm{C}$ and $S=34.64$ have been previously combined in several studies to represent hydrographic thresholds for defining the AABW limits (e.g., Wepperning et al., 1996; Meredith et al., 2000; Klatt et al., 2005). This definition is generally coincident with the more recent $\gamma^{\mathrm{n}}=28.27 \mathrm{~kg} \mathrm{~m}^{-3}$ threshold for the open ocean regime (e.g., Orsi et al., 1999; Kerr et al., 2012) used in our study. When appropriate, both isolines are presented for comparison. 
Table 1. Summarized information on the case studies for the velocity and volume transport assessment.

\begin{tabular}{|c|c|c|c|c|}
\hline Case study & $\begin{array}{l}\text { Case study I: } \\
\text { Kerguelen Plateau/ } \\
\text { Indian sector }\end{array}$ & $\begin{array}{l}\text { Case study II: } \\
\text { Endurance Ridge/ } \\
\text { Weddell Sea sector }\end{array}$ & $\begin{array}{l}\text { Case study III: } \\
\text { Prime Meridian/ } \\
\text { Weddell Sea sector }\end{array}$ & $\begin{array}{l}\text { Case study IV: } \\
\text { Western Weddell Sea/ } \\
\text { Weddell Sea sector }\end{array}$ \\
\hline Section & Section I & - & Section IV & Sections II and III \\
\hline Previous references & Fukamachi et al. (2010) (F10) & Gordon et al. (2010) & $\begin{array}{l}\text { Klatt et al. (2005) (K05) and } \\
\text { Fahrbach et al. (2011) }\end{array}$ & $\begin{array}{l}\text { Fahrbach et al. (2001) (F01) and } \\
\text { Kerr et al. (2012) (K12) }\end{array}$ \\
\hline Data period & 02/2003-01/2005 & $2000-2007$ & 1996-2008 & 1989-1998 \\
\hline $\begin{array}{l}\text { Data from previous studies } \\
\text { used for comparison }\end{array}$ & $\begin{array}{l}\text { AABW volume transport time } \\
\text { series }\end{array}$ & $\begin{array}{l}\text { Current meter time series from } \\
\text { moorings } \mathrm{M} 2 \text { and } \mathrm{M} 3\end{array}$ & $\begin{array}{l}\text { Zonal velocity from moorings } \\
\text { M229 and M } 233\end{array}$ & $\begin{array}{l}\text { WSBW and AABW volume transport } \\
\text { time series from F } 01 \text { and } \mathrm{K} 12 \text {, respec- } \\
\text { tively; velocity time series from F01 }\end{array}$ \\
\hline Variables evaluated & $\begin{array}{l}\text { AABW volume transport time } \\
\text { series }\end{array}$ & Current velocity time series & $\begin{array}{l}\text { Current velocity time series AABW } \\
\text { and water column volume transport } \\
\text { time series }\end{array}$ & $\begin{array}{l}\text { AABW and WSBW volume transport } \\
\text { time series }\end{array}$ \\
\hline
\end{tabular}

\subsection{Methods for reanalysis and observational data comparison}

\subsubsection{Hydrographic properties}

$\theta-\mathrm{S}$ diagrams and specific depth ranges for the entire Southern Ocean were evaluated to provide complementary information on the assessment of the bottom layer representation before proceeding with a detailed investigation of the AABW representation in the ECCO2 product. The $\theta-\mathrm{S}$ diagrams depict basic information regarding the distribution of hydrographic properties throughout the entire water column, while the averaged depth ranges are used to evaluate the geographical distribution of hydrographic properties in strata that involve the core water masses important for AABW formation.

Three depth ranges were selected for determining climatological averages. The surface (SL), intermediate (IL), and bottom (BL) layers result from the average of the ECCO2 levels at 100-150, 409-634, and $3000 \mathrm{~m}$ to the seabed, respectively. The SL includes the shelf water masses and the mixture of water masses at the continental slope. The IL encompasses the WDW core in the Weddell Sea (Orsi et al., 1993), which corresponds to the water mass at intermediate depths that reaches the continental slope and contributes to dense water formation. The BL includes both deep and bottom water masses. The observational data were also averaged into those levels, and both data sets were spatially averaged into a $1^{\circ}$ grid to allow the determination of the differences between fields. These estimates were the only case in which the data from the entire year period were considered. Further reanalysis-observation comparisons presented here were made based only on data from the austral summer (defined here from November to March) to avoid a possible bias because of a lack of observations during other seasons. The time average of observational data was calculated to consider the entire period available (1958-2011) and just the period of the ECCO2 reanalysis output (1992-2011). The reanalysis and observational data averages presented high correlation $(r \geq 0.8)$ considering both time coverages for all layers and hydrographic properties $\left(\theta, S\right.$, and $\left.\gamma^{\mathrm{n}}\right)$. We follow our analysis using the observational data set restricted to the 1992-2011 period to avoid possible biases because of decadal and lower frequency variability during the 50-year period.

To quantify how well the reanalysis output reproduces the observed Southern Ocean hydrographic properties, the similarity between the averaged fields was characterized in terms of statistical parameters regarding both data sets. Considering the regional differences of hydrographic properties and processes within the Southern Ocean, the study area was divided into five hydrographic sectors according to Cavalieri and Parkinson's (2008) definition: the Bellingshausen and Amundsen Sea (B\&A), the Ross Sea, the Western Pacific, the Indian, and the Weddell Sea sectors (Fig. 1). In each sector, the correlation coefficient, centered root-mean-square (CRMS) difference, and standard deviations were computed for the previously defined layers (SL, IL, and BL) from both data sets and considering each hydrographic parameter $\theta$, $S$, and $\gamma^{\mathrm{n}}$ ). These statistical parameters are summarized in a Taylor (2001) diagram in which the observational field is considered as a reference (WOD). Reanalysis fields that are more consistent with observations will be located closer to the "reference" point. The closer the reanalysis standard deviation is to the observational standard deviation, the better the spatial patterns are represented.

Using the ECCO2 monthly fields corresponding to the occupation dates of WOCE sections SR2, SR3, and SR4, we selected the reanalysis grid points closer to the observations. The data sets have different vertical resolutions, and the measurement positions change among occupations. To allow for a comparison, data from both data sets were averaged onto a regular grid and then averaged over time. The vertical resolution of the grid followed the depth levels from the reanalysis, whereas the horizontal resolution was $0.5^{\circ}$ latitude (WOCE SR2 and SR3) and $1^{\circ}$ longitude (WOCE SR4).

We calculated the percentage of area occupied by the AABW in each section and also the averaged $\gamma^{\mathrm{n}}$ of this layer. Similar calculations were made by Fahrbach et al. (2004) and Renner et al. (2009) in the Weddell Sea. The averaged hydrographic properties from the occupations that did not extend to the entire section (WOCE SR2: March 1999, WOCE 
SR3: March 1996, and WOCE SR4: November 1992 and April 1998) were not directly compared with the results from other occupations to avoid bias resulting from the differences in properties along the sections.

\subsubsection{Ocean current velocity and volume transport}

The performance of the ECCO2 reanalysis in representing ocean current velocity and volume transport of dense water masses was evaluated in specific case studies based on the results and data presented by previous studies (e.g., Fahrbach et al., 2001, 2011; Klatt et al., 2005; Gordon et al., 2010; Fukamachi et al., 2010; Kerr et al., 2012). In all cases, even when the raw observational data were used (e.g., Klatt et al., 2005; Gordon et al., 2010), we sought to follow the original methodology as closely as possible to produce robustness for the reanalysis-observation comparisons.

The ECCO2 grid points that were closest to the array of eight current-meter moorings on the eastern flank of the Kerguelen plateau (February 2003 to January 2005, Fukamachi et al., 2010; Section I in Fig. 1) were selected for reanalysis-observation comparison in the Indian sector of the Southern Ocean. The ocean current velocity components were rotated to the section orientation, and the cross-section component was used to determine the AABW volume transport. The AABW transport was integrated from the southwestern section limit to the zero crossing point from the northwestward to the southeastward flow. The AABW definition used for the volume transport calculation follows our previously defined threshold (i.e., $\gamma^{\mathrm{n}}=28.27 \mathrm{~kg} \mathrm{~m}^{-3}$ ) for consistency throughout the manuscript. However, in this section, the $\mathrm{AABW}$ produced by the reanalysis is warmer than expected. Consequently, the isotherm limit used by Fukamachi (2010) (i.e., waters colder than $0^{\circ} \mathrm{C}$ ) is not present in the reanalysis section during the comparison period.

The M2 and M3 oceanographic moorings were deployed in 1999 at the continental slope of the South Orkney plateau and were equipped with two current meters (data available for 2000-2007): one at $\sim 15 \mathrm{~m}$ and the other at $\sim 500 \mathrm{~m}$ from the bottom (Fig. 1). More details on the mooring data can be found in Gordon et al. (2010). We selected the ECCO2 grid points closest to the mooring positions and extracted $u$ and $v$ values from the depth level corresponding to the bottom current meters present at M2 $(\sim 3100 \mathrm{~m}, 2999 \mathrm{~m}$ in the reanalysis) and M3 ( $\sim 4580 \mathrm{~m}, 4264 \mathrm{~m}$ in the reanalysis).

An array of moored current-meters along the Prime Meridian (between 69.5 and $57^{\circ} \mathrm{S}$ ) collected data from 1996 to 2000 (Klatt et al., 2005). Measurements from 2001 to 2008 from the same locations were added to this data set (Fahrbach et al., 2011). The zonal velocity from the reanalysis output was extracted for the position of mooring M233 (1950 m; $69.4^{\circ} \mathrm{S}$ and $0^{\circ} \mathrm{E}$ ) (Fig. 1), located at a depth of $2000 \mathrm{~m}$. The mooring is immersed within the Antarctic Coastal Current near the Antarctic continental slope. A time series of reanalysis volume transport perpendicular to Section IV was de- termined based on the ECCO2 grid points south of $60^{\circ} \mathrm{S}$ (Fig. 1).

To compare our results with those of Fahrbach et al. (2001), we selected the ECCO2 grid points closest to the four current meter moorings maintained on the northwestern Weddell Sea (1989-1998; Fahrbach et al., 2001; Section II in Fig. 1). The velocity components were rotated to represent the currents perpendicular to the section. In Fahrbach et al. (2001), the WSBW volume transport time series was determined following the threshold of $\theta \leq-0.7^{\circ} \mathrm{C}$. We maintained the AABW neutral density definition throughout this study (i.e., $\gamma^{\mathrm{n}} \geq 28.27 \mathrm{~kg} \mathrm{~m}^{-3}$ ), including for the evaluation of dense water transport variability. This assessment can be performed because the AABW properties are partly controlled by the WSBW formation (e.g., Orsi et al., 1999). However, during the comparison period, the deep and bottom waters reproduced by the reanalysis are warmer than the observations in this section; thus, the $\theta=-0.7^{\circ} \mathrm{C}$ isotherm is absent.

\subsubsection{AABW variability}

The variability of the AABW layer from reanalysis output was evaluated by linear trends of annual time series from hydrographic properties for each regional sector (bins with no data were not considered in the calculations). Sensitivity analyses of the annual trends were determined based on all months of the years and the original grid resolution $\left(0.25^{\circ} \times 0.25^{\circ}\right)$.

The temporal change in the AABW layer thickness was analyzed by determining the evolution of 4-year averages over time. At each grid point, the top of the AABW layer was considered as the shallowest occurrence of $\gamma^{\mathrm{n}} \geq 28.27 \mathrm{~kg} \mathrm{~m}^{-3}$ in the neutral density field averaged for each 4-year period. The bottom of the layer was assumed to be the seabed. Bathymetric data were obtained from the ETOPO2v2 Global Gridded 2-Minute database (US National Geophysical Data Center, http://www.ngdc.noaa.gov/ $\mathrm{mgg} / \mathrm{global} /$ etopo2.html).

\section{ECCO2 Southern Ocean representation}

\subsection{Climatological representation of the Southern Ocean water masses}

The general distribution of the hydrographic properties represented by the reanalysis in the $\theta-\mathrm{S}$ space agrees with the observations (Fig. 2). Nonetheless, the reanalysis maximum salinity values are displaced toward lower absolute values for all sectors. Such a displacement is represented by relatively fresh intermediate waters in the reanalysis output and ultimately indicates an underrepresented penetration of the North Atlantic Deep Water (NADW) into the study area. The $\mathrm{AABW}$ is present in all sectors; however, the colder and saltier bottom water variety from each sector is not repre- 

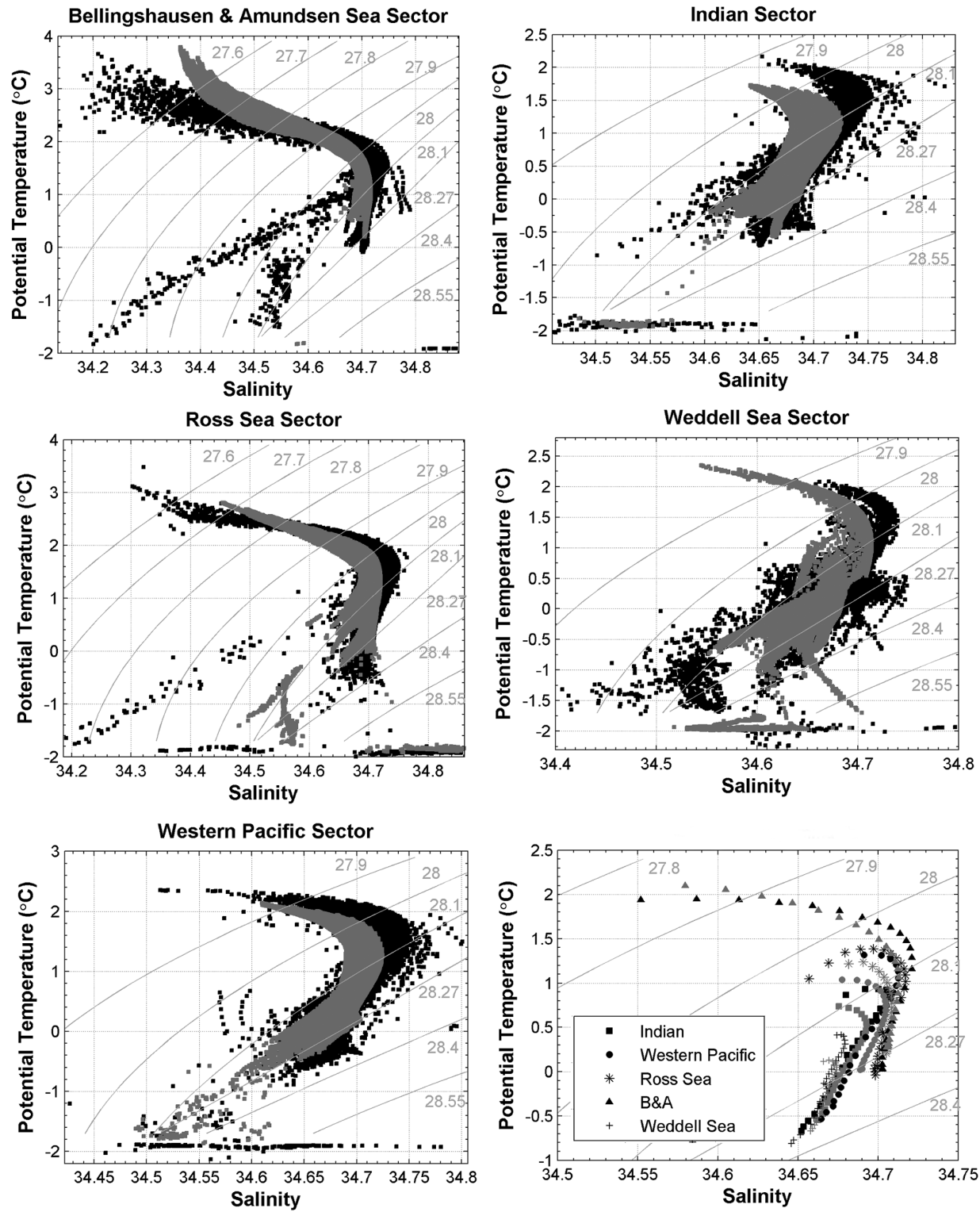

Figure 2. Twenty-year (1992-2011) average (summer only) $\theta-\mathrm{S}$ diagrams for the water column deeper than $500 \mathrm{~m}$ within each Southern Ocean sector, as defined in Fig. 1. The observational data set was averaged on the reanalysis grid and then averaged with respect to time (1992-2011). Solid lines represent the neutral density isopycnals $\left(\gamma^{\mathrm{n}} ; \mathrm{kg} \mathrm{m}^{-3}\right)$. Gray (black) dots refer to the ECCO2 (observation) data. The bottom right panel includes the areal average of all Southern Ocean sectors that are distinguished by the marker, as indicated by the legend.

sented. One exception is the densest bottom water layer from the Weddell Sea (WSBW; $\gamma^{\mathrm{n}} \geq 28.4 \mathrm{~kg} \mathrm{~m}^{3}$ ).

Although the reanalysis output can reproduce the average shape of the $\theta-S$ diagrams from observational data, additional results show that the water masses in most of the Southern Ocean are poorly represented by the ECCO2 product during the last 8 years evaluated in this study (2004-2011). The spatial distribution of the hydrographic properties over the last 8 years of the data set (2004-2011; Fig. 3) shows the appearance of a dense plume in the SL dur- ing the period 2006-2007. In the last two years, waters with $\gamma^{\mathrm{n}} \geq 28.4 \mathrm{~kg} \mathrm{~m}^{-3}$ not only fill the deep basins of the Weddell Sea but also reach the surface and spread within the region. Abrupt changes in water masses can be identified since 2004 in the AABW area estimates (see Sect. 3.2), with dense waters occupying most of the water column in some regions at the end of the studied period. These hydrographic conditions are clearly not observed in the real ocean and suggest that the representation of physical processes in the $\mathrm{ECCO} 2$ product is inadequate during this period. 

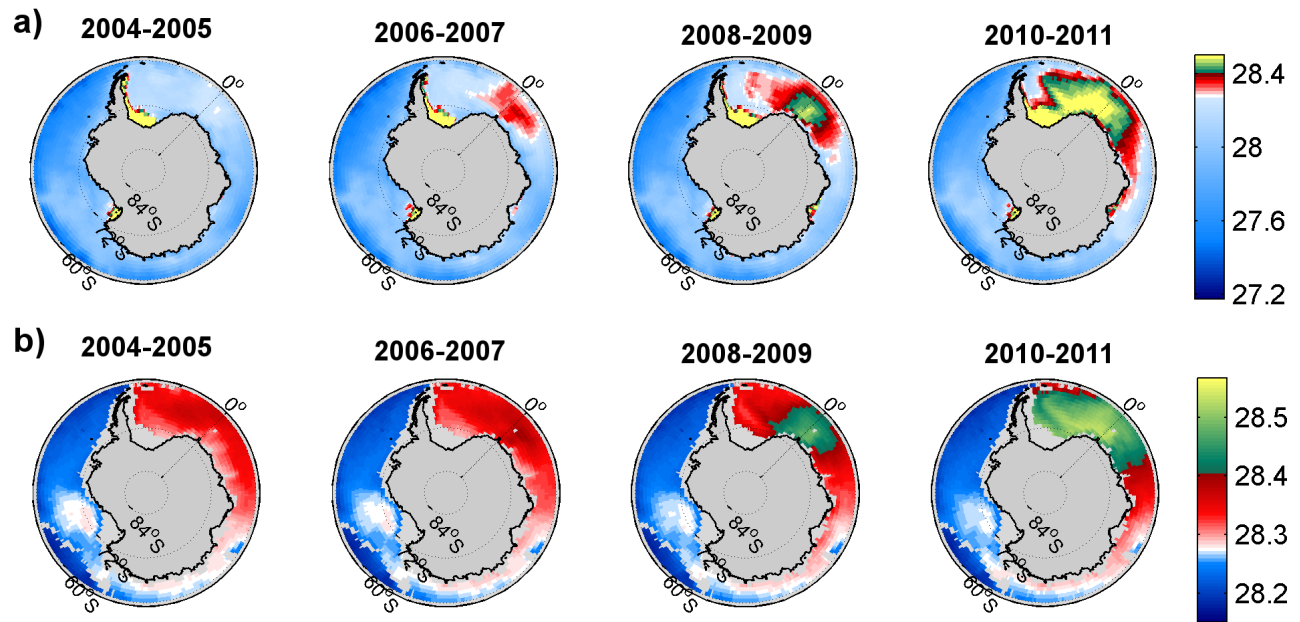

Figure 3. Two-year ECCO2 average density fields in the (a) SL and (b) BL from 2004 to 2011. Blue denotes waters lighter than $\gamma^{\mathrm{n}}=28.27 \mathrm{~kg} \mathrm{~m}^{-3}$.

a)

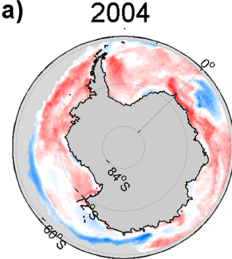

2008

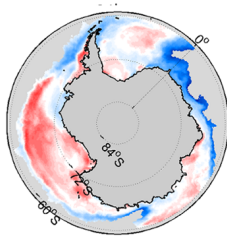

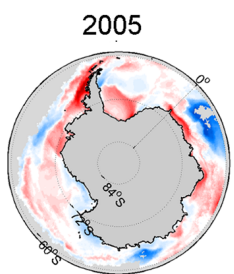

2009

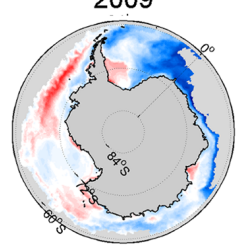

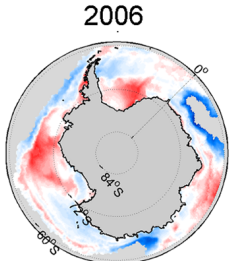

2010

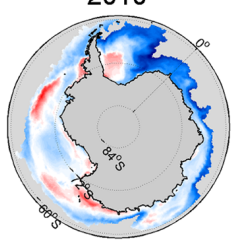

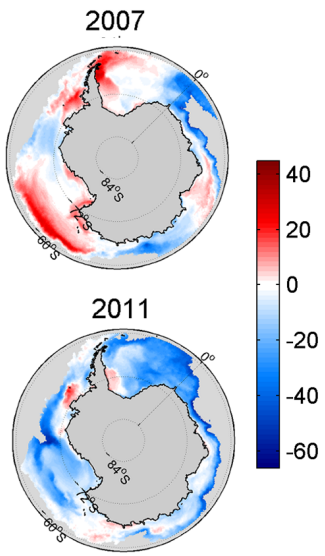

b)

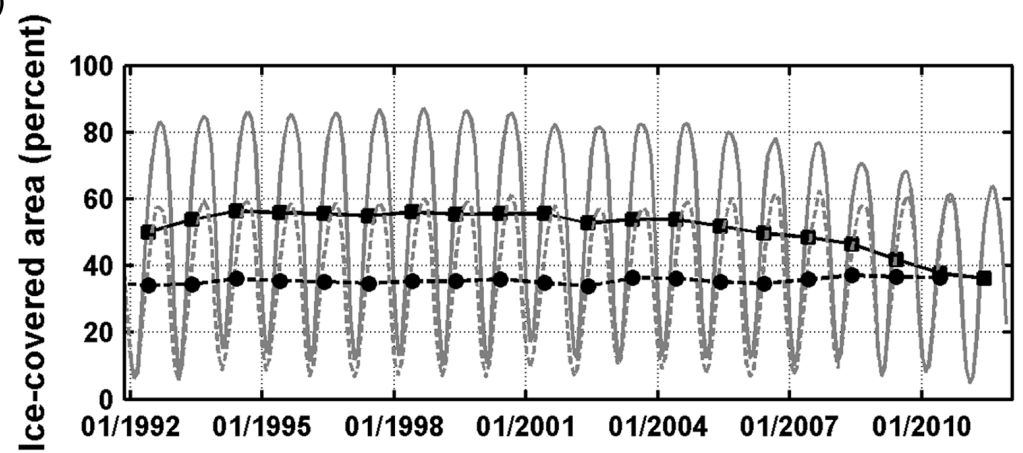

Figure 4. (a) ECCO2 sea ice area (\%) annual anomalies relative to the long-term (1992-2011) average for the period 2004-2011. (b) Comparison of monthly (gray) and annual (black) time series of sea ice area (\%) from the ECCO2 (solid line) and remote sensing (dashed line) data.

For a better understanding of the unrealistic representation of hydrographic conditions in the last few years of the ECCO 2 output, we evaluated the sea ice field reproduced by the reanalysis. The annual anomalies in the sea ice concentration (with respect to the 1992-2011 average; Fig. 4a) show that the decrease of this parameter culminated with the opening of an open ocean polynya east of the Prime Meridian in 2005 and the subsequent retreat of sea ice in the following years. The sea ice concentration time series (Fig. 4b) exhibit two main temporal changes: a reduction in the maximum 

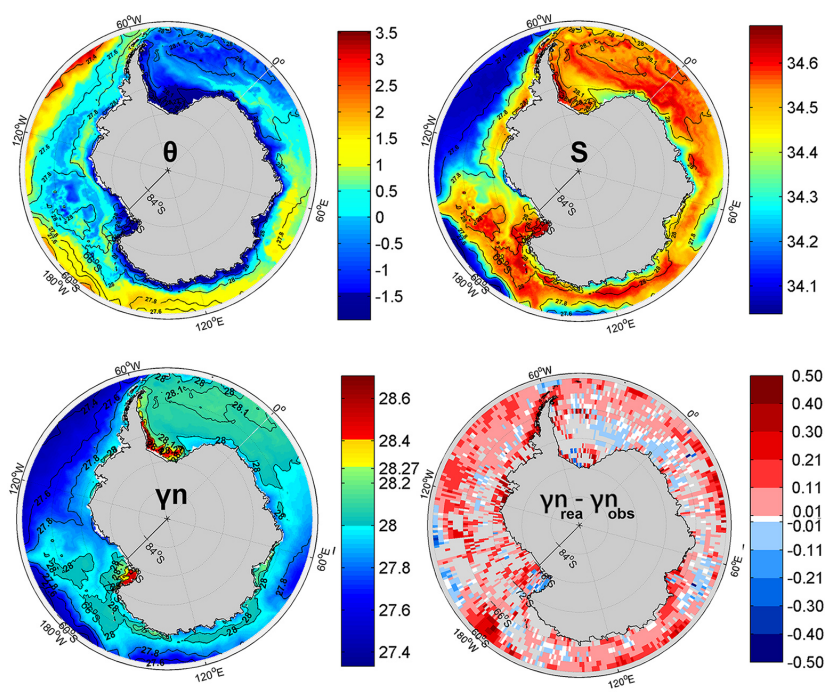

Figure 5. ECCO2 average fields (1992-2004) of $\theta, S$, and $\gamma^{\mathrm{n}}$ for the SL (100-150 m). Black contours indicate isopycnals (units are $\mathrm{kg} \mathrm{m}^{-3}$ ). The bottom right panel shows the difference between the reanalysis and observed density fields.

winter values in 2001 and a more evident decreasing trend after 2004. Sea ice thickness also exhibits a similar pattern; however, the maximum thickness decreased after 1998 (not shown). The time series also show a strong seasonality. In winter, the reanalysis output overestimates the satellite data by more than $20 \%$. However, in summer, the difference between the reanalysis and satellite data is less than $5 \%$. In the final years of the studied period, the sea ice concentration time series produced by the reanalysis are more consistent with the satellite observations. However, this reduction in the sea ice coverage results primarily from the polynya surging and the unrealistic sea ice retreat in the Weddell Sea and Indian Ocean sectors.

The aforementioned sea ice features possibly contributed, and are highly related, to the large amount of dense water reproduced by the ECCO2 product in most of the Southern Ocean after 2004. In the coupled MITgcm, the surface wind stress and both heat and freshwater fluxes are computed from atmospheric states that are modified by a sea ice model at each time step (Adcroft et al., 2012). Changes in the sea ice concentration directly affect the formation of AABW by altering the heat flux, sea ice melting, and brine rejection; moreover, changes in the sea ice concentration also affect the formation of $\mathrm{AABW}$ due to the effect of these changes on the transference of momentum from wind to ocean currents (Curry and Webster, 1999).

Sea ice thickness and compactness strongly moderate the occurrence of deep convection in the Weddell Sea region (Martin et al., 2013). Several factors, such as brine rejection from extensive sea ice formation (Heuzé et al., 2013), can contribute to decreasing the stability of the water column and initiating convective mixing. Cold surface waters mix
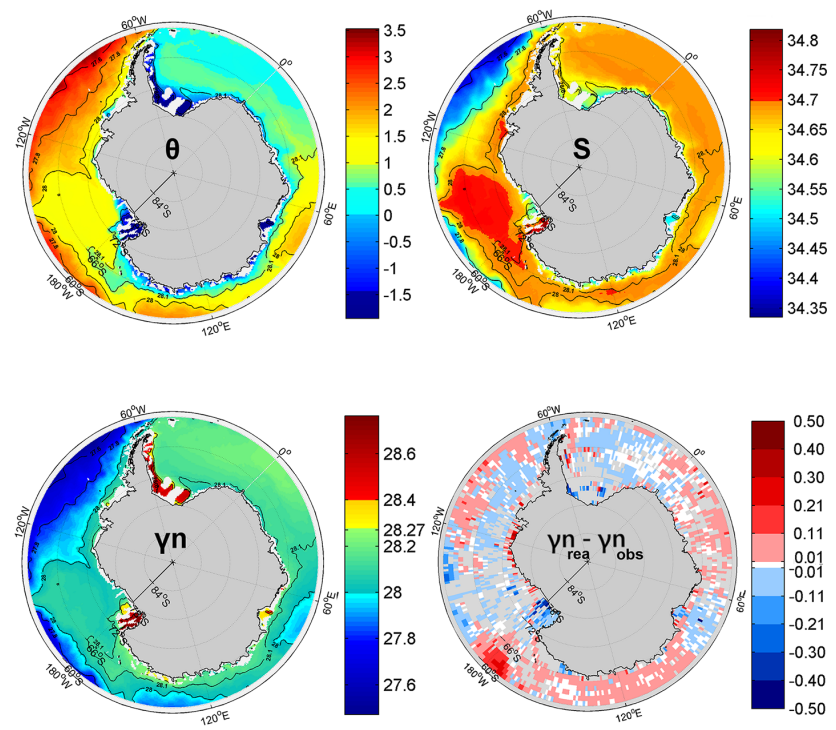

Figure 6. Same as in Fig. 5 except for the IL (409-634 m).

with warmer and saltier intermediate waters. The heat transported to the surface impedes the formation of new ice, which helps maintain the polynya, while heat loss at the surface leads to the cooling of deep waters (Morales Maqueda et al., 2004). This mechanism leads to a high production of dense waters that are directly injected into deeper levels (normally below $2000 \mathrm{~m}$ ) in the open ocean area of the Weddell Sea primarily after 2004. A further retreat in the sea ice after the polynya formation can also contribute to the intensification of ocean currents via the transference of momentum from wind to ocean currents, which facilitates the spreading of the AABW dense plume. As a result, the hydrographic properties of the Southern Ocean are inadequately represented during most of the recent years in the ECCO2 reanalysis output (2004-2011); therefore, this period is treated with caution in the subsequent analysis and is disregarded in time average estimates.

The exclusion of the 2004-2011 anomalous period from the temporal average does not induce substantial changes in the shape of the $\theta-S$ diagrams (not shown). However, when only the period from 1992 to 2004 is considered, the ratio between the volume of waters with densities between 28.1 and $28.4 \mathrm{~kg} \mathrm{~m}^{-3}$ relative to waters denser than $28.27 \mathrm{~kg} \mathrm{~m}^{-3}$ increased 7-fold in the Weddell Sea sector and 1.12-fold in the Indian Ocean sector.

The major oceanographic features are spatially reproduced by the reanalysis output in the averaged fields (1992-2004) of $\theta, S$, and $\gamma^{\mathrm{n}}$ for each defined layer (i.e., SL, IL, and BL) (Figs. 5, 6, and 7). In the SL (Fig. 5), the coldest water mass is observed in the southern Weddell Sea shelf $\left(\sim-1.9^{\circ} \mathrm{C}\right)$. Shelf waters with the highest salinities $(S \geq 34.55)$ are present in the Ross and Weddell Sea continental shelves. The densest $\left(\gamma^{\mathrm{n}} \geq 28.4 \mathrm{~kg} \mathrm{~m}^{-3}\right)$ water masses are located in the 
south and southwestern portion of the Weddell Sea continental shelf and western shelf of the Ross Sea. Relatively less dense waters $\left(\gamma^{\mathrm{n}} \sim 28.27 \mathrm{~kg} \mathrm{~m}^{-3}\right)$ are present in the northwestern Weddell Sea shelf. Waters with $\theta \leq-1.5^{\circ} \mathrm{C}$ are present in the Weddell Sea, Ross Sea, and Prydz Bay continental shelves in the averaged IL field (Fig. 6). The IL contains the core of the Circumpolar Deep Water (CDW). Thus, the open ocean regime of the Weddell Sea exhibits $\theta$ values that are relatively lower $\left(0^{\circ} \mathrm{C} \leq \theta \leq 1^{\circ} \mathrm{C}\right)$ than those in the other sections. This occurs due to the temperature attenuation caused by mixing of the Winter Water and CDW while it flows along the Weddell Gyre (WG) (Weppernig et al., 1996), resulting in WDW formation. The Ross Sea presents the saltiest water masses of all the shelves $(S \geq 34.72)$ and the open ocean $(S \geq 34.7)$ in the IL. The densest waters $\left(\gamma^{\mathrm{n}} \geq 28.27 \mathrm{~kg} \mathrm{~m}^{-3}\right)$ of the IL fill the southern and western portions of the Weddell Sea shelf region and west of the Ross Sea shelf. The general features of the BL (Fig. 7) are consistent with the description by Orsi et al. (1999) regarding the differences in bottom waters between basins based on observational data. According to Orsi et al. (1999), the coldest and freshest bottom water masses occur in the southwestern Weddell Sea sector, the warmest and saltiest waters are found in the northwestern Ross Sea sector, and intermediate characteristics are present in the Western Pacific sector. The Weddell Sea and western region of the Indian sectors present the densest bottom water masses $\left(\gamma^{\mathrm{n}} \geq 28.3 \mathrm{~kg} \mathrm{~m}^{-3}\right)$. The Ross Sea and B\&A sectors encompass waters lighter than $\gamma^{\mathrm{n}}=28.27 \mathrm{~kg} \mathrm{~m}^{-3}$ (the AABW threshold), which are limited to the Ross gyre region.

Despite the reproduction of the main oceanographic features by the ECCO2 reanalysis output, there are certain discrepancies regarding the absolute $\theta-\mathrm{S}$ values that lead to differences between density fields (Figs. 5, 6, and 7). The $\theta$ and $S$ difference fields are presented in the Supplement (Fig. S1). The reanalysis representation of the SL in the Southern Ocean is generally denser than the observations (Fig. 5), which is primarily because the waters are saltier than expected. As a result of a fresher intermediate layer, the IL density is underestimated in the B\&A and Ross Sea sectors (Fig. 6). The Weddell Sea is also represented by a relatively low density; however, this finding is related to the temperature overestimation and the close similarity of the salinity values to the expected values (i.e., a difference of between -0.01 and 0.01). In the Indian and Western Pacific sectors, the temperature underestimation leads to waters that are denser than observations. In the BL (Fig. 7), the deep water masses are predominantly lighter than suggested by the observations, which is caused by waters that are warmer than expected and by the general absence of colder bottom water variety of the AABW.

The relative accuracy of the ECCO2 reanalysis in representing the $\theta, S$, and $\gamma^{\mathrm{n}}$ fields at the defined layers during the reliable period is summarized in a Taylor diagram. The hydrographic properties are not equally well represented be-
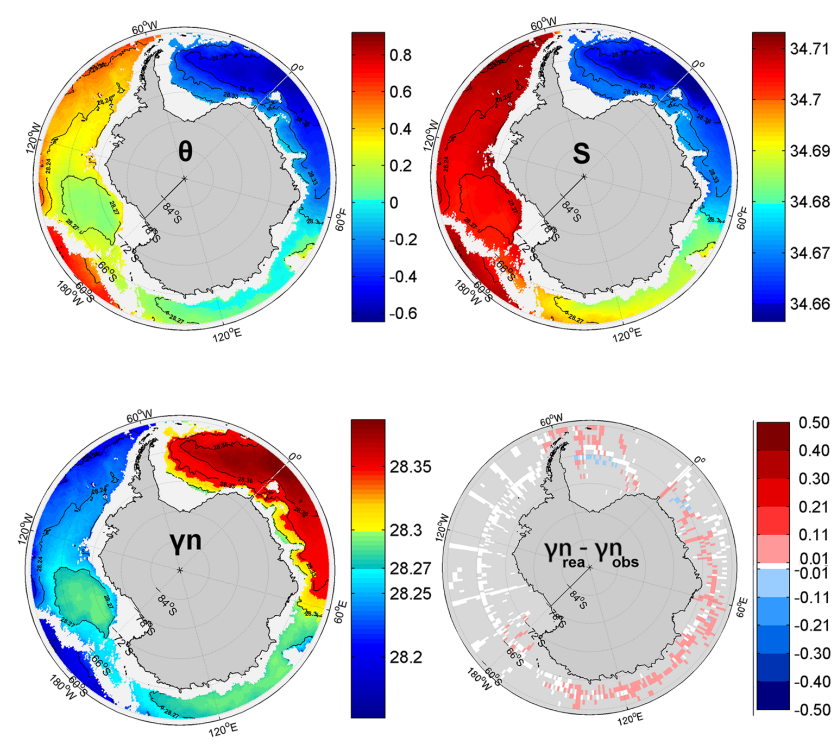

Figure 7. Same as in Fig. 5 except for the BL $(3000 \mathrm{~m}$ to the seabed).

tween the sectors. Most of the sectors and properties in the SL (Fig. 8a) underestimate the spatial variability of the observations $(\mathrm{SD} \leq 1)$. The Indian density field, in addition to the B\&A salinity, comprises the poorest representation of the observed fields. The Ross Sea sector density field reveals the most consistency between reanalysis and observations in the SL layer. All other sectors and parameters have correlation coefficients lower than 0.9. The temperatures in the Ross Sea, Indian, and Western Pacific sectors and the density in the B\&A sector are the best-represented fields in the IL, exhibiting correlation coefficients that exceed 0.9 (Fig. 8b). The salinity fields are the most poorly represented fields for all sectors. Every field and sector evaluated in the IL presents an SD less than 1, which indicates smaller amplitudes in the variation pattern compared with observational data. The BL field values exhibit large variations in the SD values, with salinity having the lowest values (Fig. 8c). The temperature and density fields in the Ross Sea and B\&A sectors are most similar to the observational fields. For all sectors and properties, the correlation coefficients are less than 0.8, i.e., lower than in the other layers. In general, the hydrographic properties are closer to the reference values, i.e., the properties are better represented in the IL; the poorest representation is in the BL.

The results based on the climatological ocean state indicate that the hydrographic properties represented by the reanalysis have an average distribution in the $\theta-\mathrm{S}$ space that is similar to the observations. Following the opening of the polynya in 2004, the Weddell Sea sector of the Southern Ocean became flooded with dense waters, indicating that the relevant physical processes are not correctly represented by the reanalysis during this period. Before 2004, the main 
a)

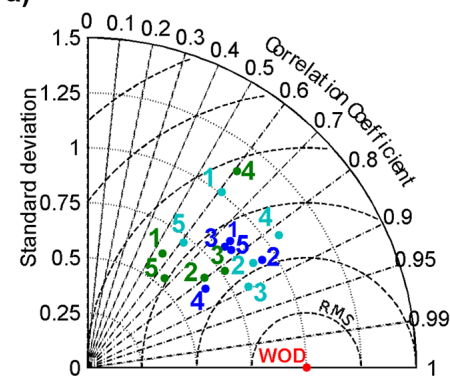

b)

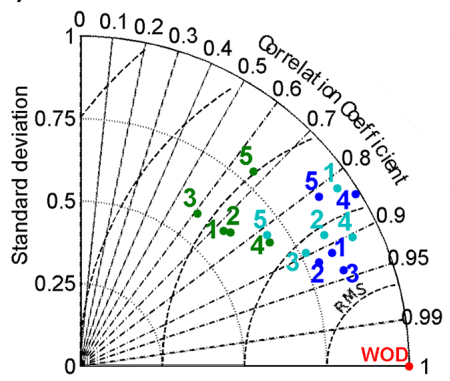

c)

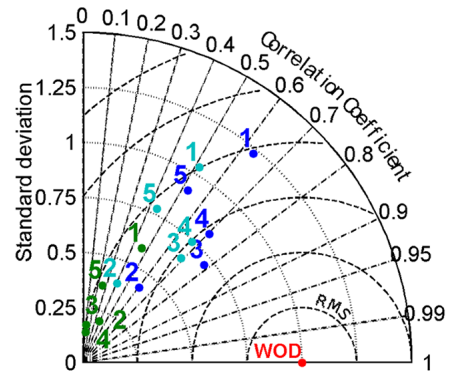

Figure 8. Taylor diagram for the period 1992-2004 within each defined layer: (a) SL (100-150 m), (b) IL (409-634 m), and (c) BL (3000 m to the seabed); the diagrams are separated according to the ocean sectors (Fig. 1) and are indicated by numbers (Indian - 1, Western Pacific - 2, Ross Sea - 3, Bellingshausen and Amundsen sectors - 4, and Weddell Sea - 5). Dark blue, green, and light blue points indicate $\theta$, $S$, and $\gamma_{\mathrm{n}}$, respectively. The gray curves, dashed curves, and dashed radii refer to the normalized standard deviation, centered root-mean-square error, and correlation, respectively. WOD refers to the observed data set used as a reference for the comparison (see the text for details).
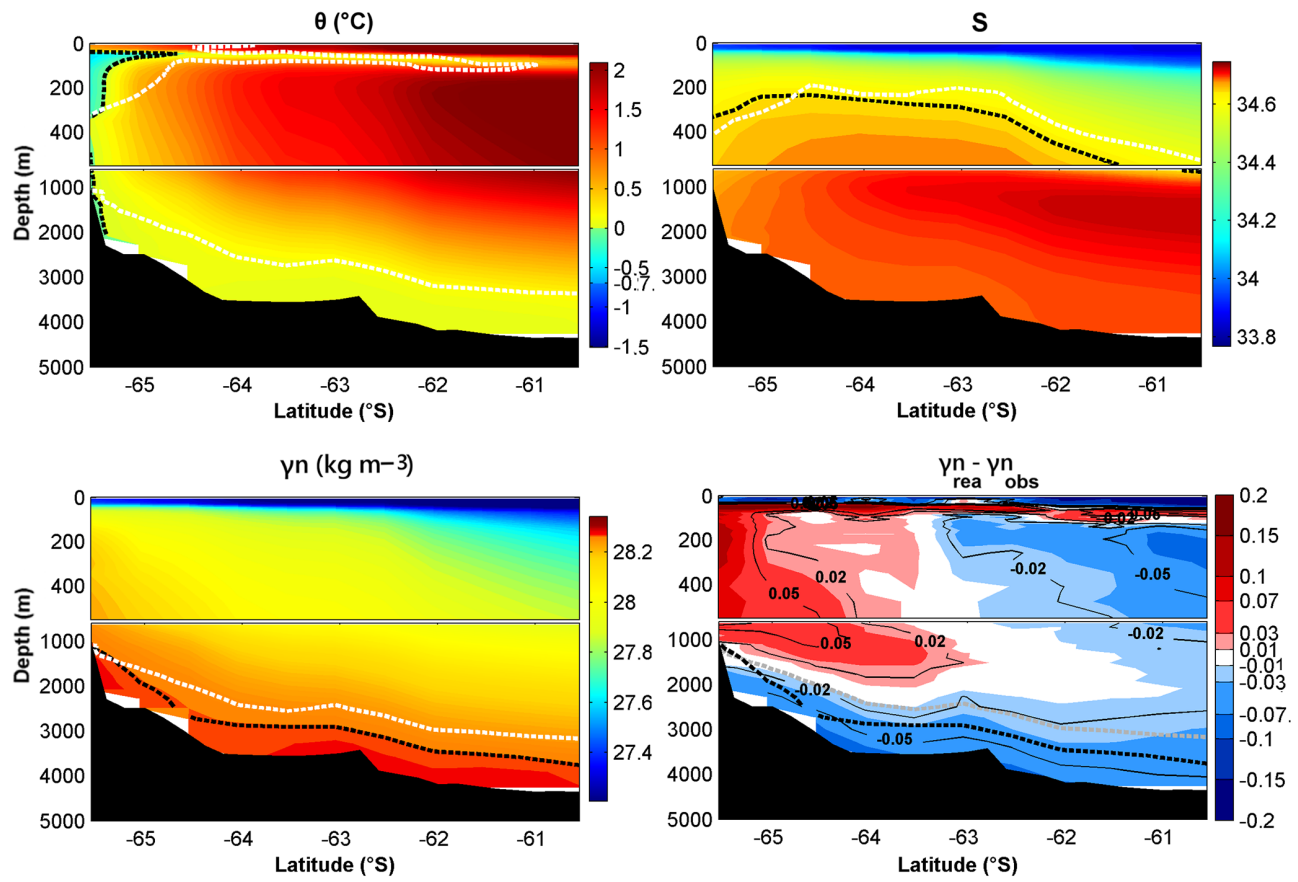

Figure 9. Hydrographic properties of the repeat section WOCE SR3. Average fields of $\theta, S$, and $\gamma_{\mathrm{n}}$ during section occupations are presented for the ECCO2 data. The bottom-right panel refers to the difference between the reanalysis and observed density fields. Dotted lines indicate isolines of $\theta=0{ }^{\circ} \mathrm{C}, S=34.64$, and $\gamma^{\mathrm{n}}=28.27 \mathrm{~kg} \mathrm{~m}^{-3}$ based on the ECCO2 reanalysis (black) and observations (white).

oceanographic surface water features are reproduced by the reanalysis; however, these waters are generally denser than suggested in the observations, while deep waters are primarily less dense than expected. The intermediate layer is statistically the closest to the observations, while the deep waters have the worst representation. The misrepresentation of surface waters is possibly due to the lack of accuracy in reproducing several complex processes that act on the ocean surface in the reanalysis output. This limitation is compounded in coastal waters by the absence of ice shelf water, an important predecessor of AABW (Foldvik et al., 2004). This ab- sence was expected because ice shelves are not considered in the ECCO2 product. Less dense deep waters are related to the lack of the coldest and densest AABW varieties, which possibly result from the absence of newly formed dense waters spilling off the shelf in the reanalysis. Moreover, the coarse vertical grid resolution at greater depths implies that deep waters are represented by the average properties of approximately $400 \mathrm{~m}$ of water column, which leads to a poor representation of the approximately $100 \mathrm{~m}$-thick bottom water layer. 

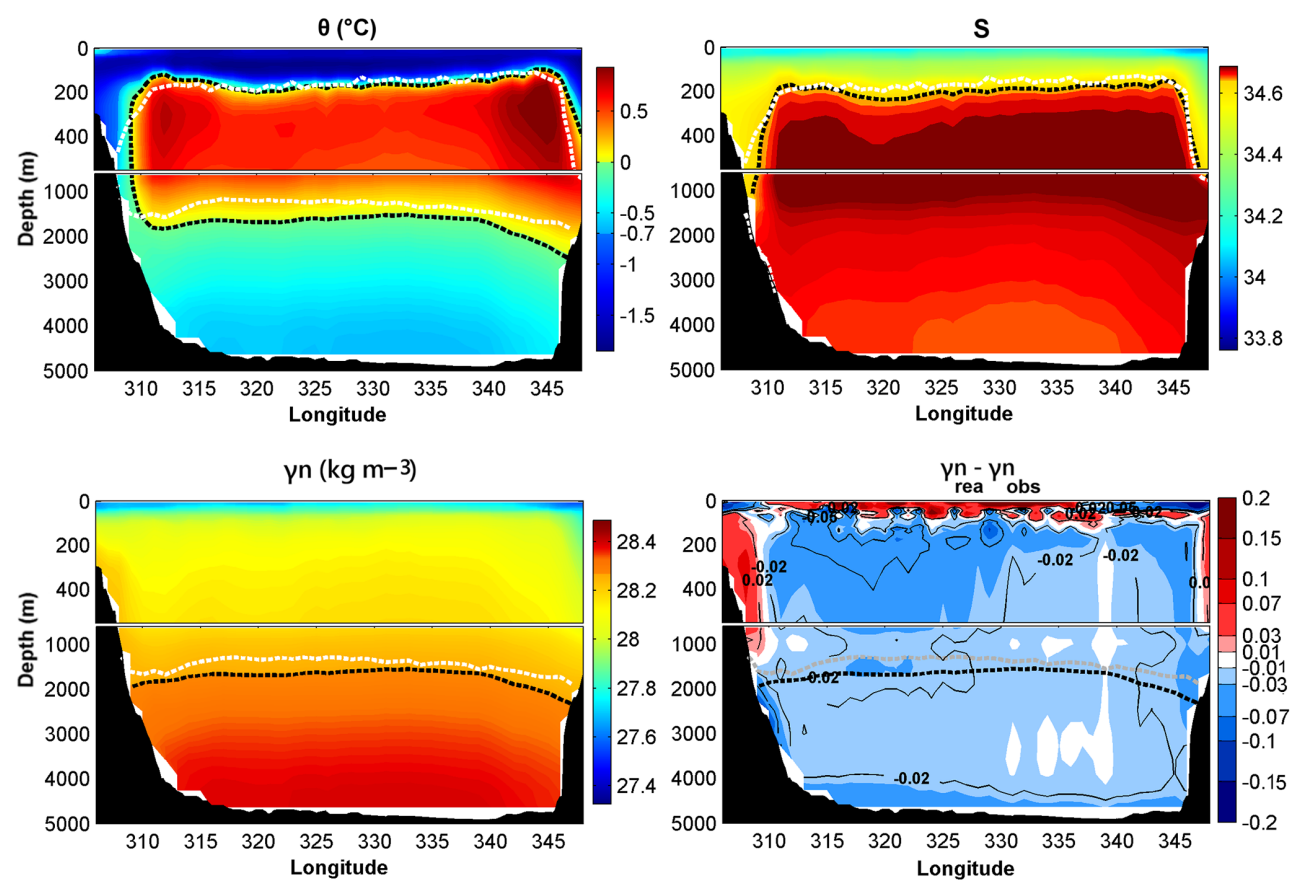

Figure 10. Same as in Fig. 9, except for section WOCE SR4.

The average differences between the reanalysis and observed fields are comparable to the performance of the more accurate models among those evaluated by Heuzé et al. (2013). The authors compared the AABW hydrographic properties of 15 climate models with observed climatology. The models considered to be most accurate by the authors exhibited temperatures, salinities and densities within $0.5^{\circ} \mathrm{C}$, 0.1 , and $0.05 \mathrm{~kg} \mathrm{~m}^{-3}$ of the observed climatology, respectively. Considering the $\mathrm{BL}$, the average differences between the ECCO2 estimates and the observations are $0.24^{\circ} \mathrm{C}, 0.09$ and $-0.038 \mathrm{~kg} \mathrm{~m}^{-3}$ for temperature, salinity, and density, respectively. These values are lower than those defined by Heuzé et al. (2013), indicating that the ECCO2 discrepancies, in terms of absolute values, are comparable to other circulation models. Moreover, most of these models also use deep convection as an important mechanism for dense water formation.

\subsection{Water mass representation along repeat hydrographic sections}

Following the previous time-averaged analysis, we considered only the period from 1992 to 2004 of the ECCO2 data set to compare the averaged hydrographic properties from observations and reanalysis output along the historical sections (Figs. 9-11). Complementary figures for the $\theta$ and $S$ difference fields can be found in the Supplement (Fig. S2).

The $0{ }^{\circ} \mathrm{C}$ isotherm from the reanalysis average temperature profile for section WOCE SR3 (Fig. 9), located within the Australian-Antarctic Basin, exhibits a more restricted ex- tension than suggested in the observations at the surface; moreover, this isotherm is absent in deep waters. This finding provides additional evidence of the overestimation of surface water temperatures and that the reanalysis bottom waters do not reach the minimum observational temperatures. Despite the coincidence of the $S=34.64$ isohaline, the salinity maximum of intermediate waters is lower than the observed values. The subsurface density overestimation is coincident with the temperature bias indicated by the $\theta=0^{\circ} \mathrm{C}$ isoline; however, this result is caused by the smaller thickness of the surface fresh water layer that is reproduced in the reanalysis compared with the observations. The change from a denser (lighter) intermediate water to the south (north) of $63^{\circ} \mathrm{S}$ coincides with the southern limit of the eastward transport ("southern ACC front"; Rintoul and Bullister, 1999), which was identified by Orsi et al. (1995) as a front located south of the polar front that is usually marked by the southernmost extent of maximum temperatures; this result is coincident with the reanalysis temperature profile. Thus, the observed change in density representation may be linked to a dynamical barrier. The temperature differences exhibited in deep waters contribute to an AABW layer that is lighter and thinner than expected. Thus, it is likely that the AABW layer in this region is primarily supplied by the relatively warmer and saltier bottom water from the Ross Sea because the colder and fresher Adelie Land Bottom Water is absent.

The property fields of the sections within the Weddell Sea and along the Prime Meridian are consistent between the reanalysis and observational data, which is indicated by the highly coincidental $0^{\circ} \mathrm{C}$ isotherm and 34.64 isohaline 

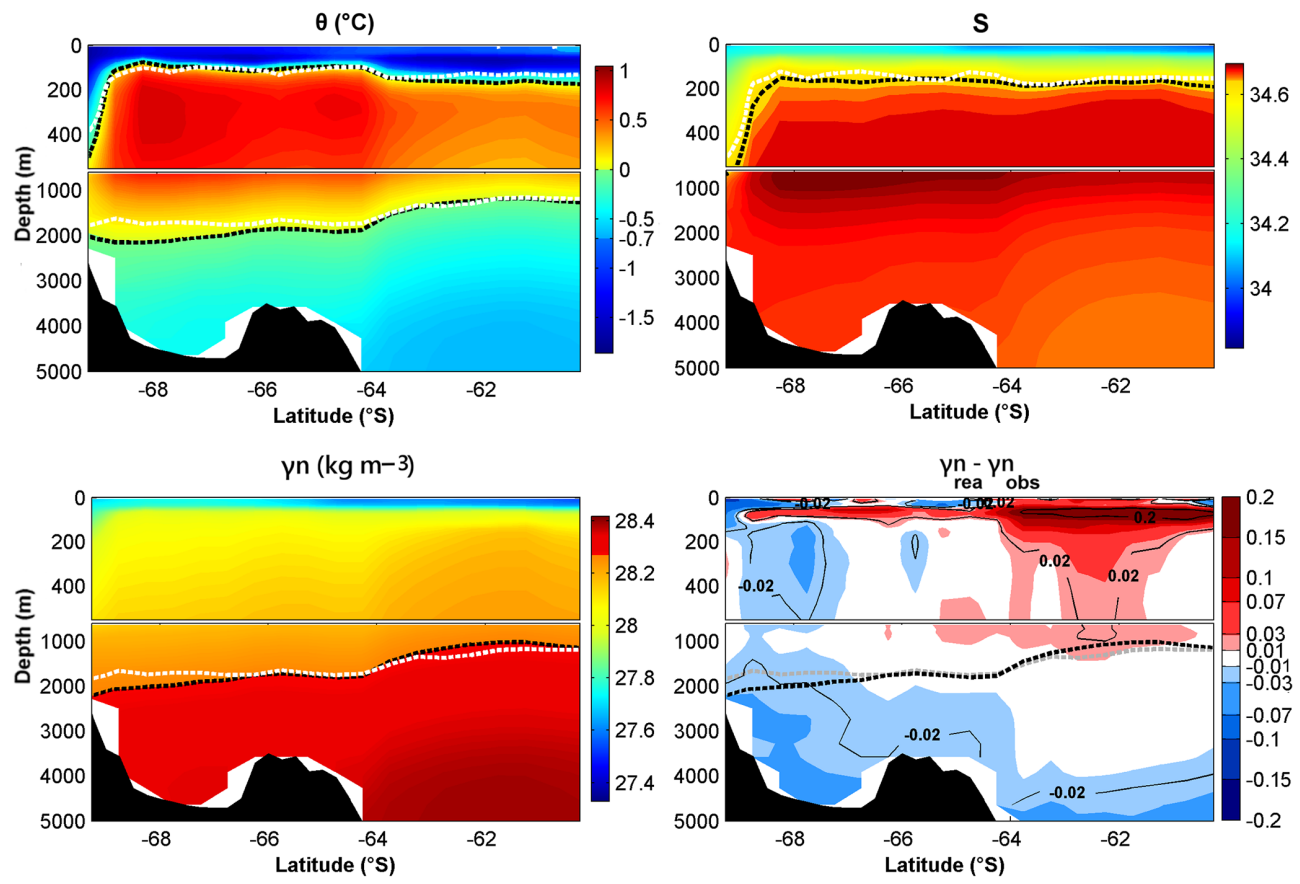

Figure 11. Same as in Fig. 9, except for section WOCE SR2.

(Figs. 10 and 11). The major regional features are represented by the reanalysis output, e.g., the characteristic doming of the Weddell Sea cyclonic gyre (Fahrbach et al., 2004) and the signature of the Antarctic slope front, which is a boundary between the shelf waters and the CDW over the Antarctic continental slope (Jacobs, 1991). The warm core of the WDW that is adjacent to the continental shelf is represented in the reanalysis for both sections. Despite the coincident $0{ }^{\circ} \mathrm{C}$ isotherm, the bottom waters do not reach the low temperatures of the WSBW $\left(-0.7^{\circ} \mathrm{C}\right)$. Consequently, the bottom waters are lighter than expected in both sections in the reanalysis product (Figs. 10 and 11, bottom-right panel); however, there is good agreement in the AABW upper limit. Therefore, in the sections within the Weddell Sea, the absence of the denser AABW variety (WSBW) is compensated in terms of volume by the WSDW. However, for section WOCE SR3, the $28.27 \mathrm{~kg} \mathrm{~m}^{-3}$ isopycnal is deeper and, consequently, the dense water layer is thinner (Fig. 9). The density overestimation at the western end of WOCE SR 4 is not associated with a dense downward flow along the continental slope. Instead, this overestimation is a result of the combination of waters that are saltier $(\sim 100$ to $400 \mathrm{~m})$ and colder ( $\sim 400$ to $1500 \mathrm{~m}$ ) than suggested by the observational data. The downward flow is not identifiable in any of the crossslope sections.

Estimates based on the reanalysis output of the area occupied by the AABW layer along WOCE sections (Fig. 12) slightly underestimate the AABW area and density before 2004 (average area differences of 14.19, 2.36, and 5.26\% for WOCE SR3, SR2, and SR4, respectively). The larger differ- ences in the AABW area found in WOCE SR3 were expected because the $28.27 \mathrm{~kg} \mathrm{~m}^{-3}$ isopycnal was deeper than suggested by the observations in the averaged section (Fig. 9). The WOCE SR3 time series (Fig. 12a) does not exhibit abrupt changes in any of the estimates, which is consistent considering its distance from the polynya region. However, section WOCE SR2 (Fig. 12b) exhibits an unrealistic change in the AABW area (from $\sim 66$ to $\sim 90 \%$ ) and density after 2004. At the end of the time series, AABW occupies most of the water column, which is composed of waters denser than $28.4 \mathrm{~kg} \mathrm{~m}^{-3}$ after 2008. The AABW area and density in section WOCE SR4 (Fig. 12c) begin to increase concurrently with the stabilization of the AABW area in section WOCE SR2 (approximately in 2006). Moreover, AABW fills nearly the entire water column in the final 2 years of the data set (i.e., 2010-2011). The mean differences between the estimates from the reanalysis and observational data sets are $\sim 16$ and $\sim 4$ times higher in the most recent years for sections SR2 and SR4, respectively. Clearly, observational data do not exhibit this pattern. As discussed previously, these abrupt changes in the AABW area and the mean density are the result of the high dense water production reproduced by the reanalysis during the most recent years. The opening of the polynya and the deep convection process began near the Prime Meridian; thereafter, the produced dense water was advected along the Weddell Gyre, which explains the delay between the WOCE SR 2 and SR4 property changes. Finally, these results show consistency between area estimates within the Weddell Sea from the reanalysis and observational data sets until 2004 and confirm the inability of the ECCO2 prod- 
a)
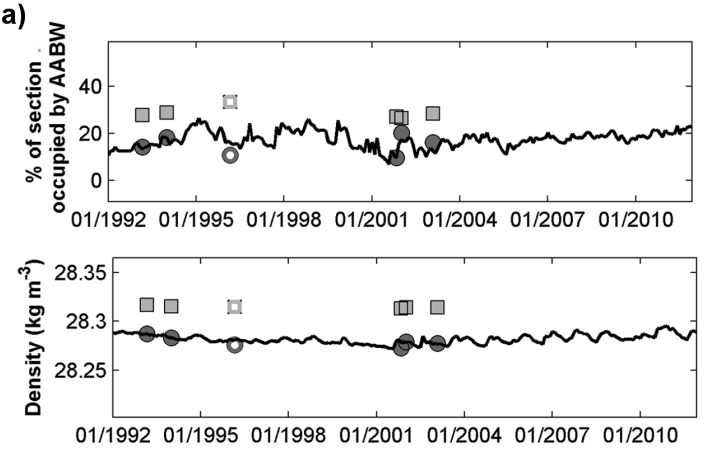

b)
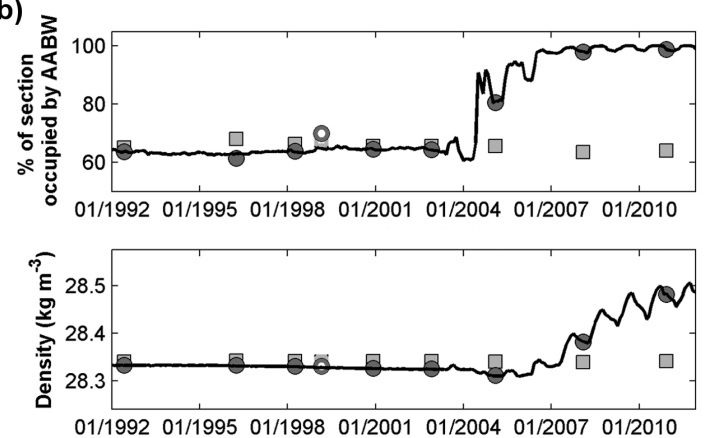

c)
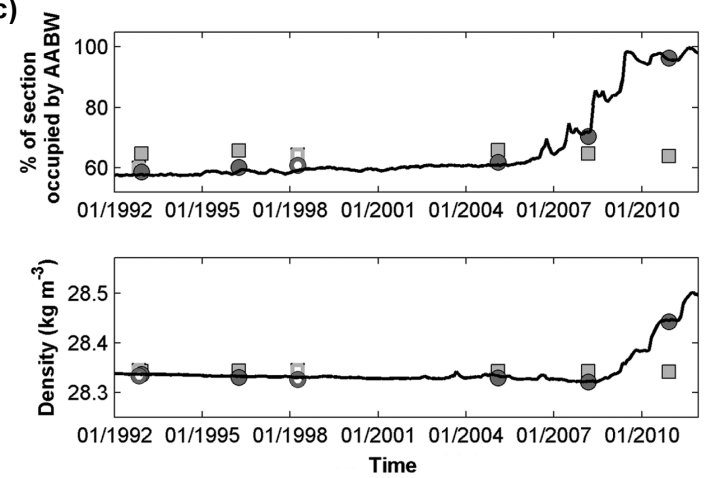

Figure 12. The percentage of the section area occupied by the AABW (upper panels) and AABW (bottom panels) layer average density for the WOCE repeat sections (a) SR3, (b) SR2, and (c) SR4. Squares denote the observed estimates. The reanalysis estimates restricted to available observations are represented by circles. Open markers denote incomplete section occupation. Black lines refer to estimates based on the complete spatial and temporal ECCO2 data.

uct to reproduce hydrographic properties and structures after 2004.

The analysis of the hydrographic properties along the three WOCE sections revealed that within the Weddell Sea (WOCE SR2 and SR4), the reanalysis is capable of representing the major hydrographic features, e.g., the doming of the Weddell Sea Gyre, WDW temperature and salinity maxima, and the Antarctic slope front before the polynya opens. The AABW upper limit and area are coincident with the observations; the average differences are less than $6 \%$ compared with the observational data estimates before 2004 .
However, in section SR3, the $28.27 \mathrm{~kg} \mathrm{~m}^{-3}$ isopycnal is deeper than expected, which leads to larger differences in the estimated area $(14 \%)$. In all sections, deep waters are warmer and less dense than expected. In the Weddell Sea, the densest AABW variety (WSBW) is absent and replaced by the warmer WSDW, while in SR3, the AABW layer is thinner. After 2004, the Weddell Sea is filled with dense waters produced by intense deep convection that occupy most of the water column at the end of the time series, producing inconsistent and unreliable hydrographic conditions.

\subsection{Velocity and volume transport assessment}

The assessment of the AABW current velocity and volume transport variability is performed in four case studies based on data previously reported in the literature (see Table 1 for details), and each case study is highlighted below.

\subsubsection{Case study I: Kerguelen Plateau/Indian sector}

The Kerguelen Plateau deep western boundary current was recently identified as a significant pathway of deep water transport from the Southern Ocean toward lower latitudes. This region (Fig. 1) is characterized by a narrow and intense northwestward flow close to the plateau and a southeastward flow offshore (Fukamachi et al., 2010; hereafter referred to as F10; case study I). Based on the $28.27 \mathrm{~kg} \mathrm{~m}^{-3} \gamma^{\mathrm{n}}$ isopycnal, the AABW layer exhibits a thickness of approximately $1500 \mathrm{~m}$ in the ECCO2 reanalysis, which coincides with F10 estimates (see the Supplement; Fig. S3). However, the AABW layer is warmer in the reanalysis than in the observations presented by F10. The ECCO2 deep western boundary current mean transport $(3.7 \pm 1.3 \mathrm{~Sv}$; Fig. 13a) during the observed period (February 2003 to January 2005) is much lower than the $12.3 \pm 5.6 \mathrm{~Sv}$ estimated by F10. After 2006, there is a continuous increase in the AABW flow (Fig. 13b) that leads to an AABW transport of $12 \mathrm{~Sv}$ at the end of the time series, which is close to the mean flow reported by F10 (i.e., 12.3 Sv). However, the years with higher AABW transport coincide with the period of active deep convection, during which the ECCO2 reanalysis produces unreliable hydrographic conditions. The reanalysis output does not represent the observational variability pattern because the correlation between time series is low $(r=-0.2)$. The rugged bathymetry and poor model spatial resolution can contribute to the difficulty of the reanalysis output reproducing the deep and bottom volume transport variability. Another important factor that could have contributed to a low correlation in this analysis is the short length of the available time series.

\subsubsection{Case study II: Endurance Ridge/Weddell Sea sector}

The deep and bottom water properties in the northern limb of the Weddell Sea were evaluated by Gordon et al. (2010) and 


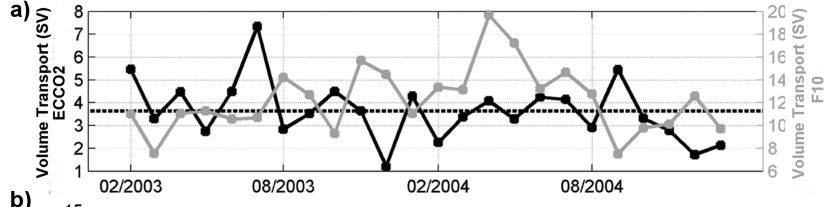

b)

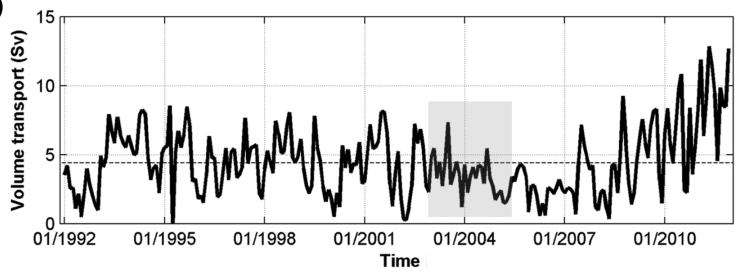

Figure 13. (a) Monthly AABW volume transport (Sv) obtained from the ECCO2 data (black line) and Fukamachi et al. (2010) (gray line) for Section I (see Fig. 1). The averaged ECCO2 reanalysis estimate is indicated by the black dotted line. (b) Monthly AABW volume transport $(\mathrm{Sv})$ from the ECCO2 data during the entire data period. The gray box highlights the period presented in panel (b).

McKee et al. (2011) using data from bottom moorings M2 $\left(3096 \mathrm{~m} ; 62^{\circ} 38^{\prime} \mathrm{S} ; 043^{\circ} 15^{\prime} \mathrm{W}\right)$ and $\mathrm{M} 3\left(4560 \mathrm{~m} ; 63^{\circ} 32^{\prime} \mathrm{S}\right.$; $41^{\circ} 47^{\prime} \mathrm{W}$ ) (Fig. 1; case study II). The latter is associated with the eastward flow of the WSBW originating in the southwestern Weddell Sea, whereas measurements from M2 are related to the WSDW formed further north. The monthly velocity time series of the deepest current meters from each mooring are well correlated $(r=0.58$ for $\mathrm{M} 2$ and $r=0.57$ for M3) with velocities from the ECCO2 reanalysis at approximately the same depths (Fig. 14a). Despite the statistical significance of these correlations, current meter M2 has a short time series and an 18-month gap during the 4-year sampling period; therefore, these correlation results should be considered with caution. The amplitude of seasonal variations is higher in the time series from observational data and more evident at M3. The different time series patterns of variability might be related to distinct water mass sources and forcing of the water flowing through each mooring. In general, the average current velocities from the reanalysis are lower than those from the observational data except during the low-current velocity periods at M3 (December, January, and February); during these periods, the velocities are very similar. During the polynya period, there is an increase in the reanalysis velocity that leads to values that are approximately the same as the observational average $\left(\sim 12 \mathrm{~cm} \mathrm{~s}^{-1}\right)$ during July 2006 at M3; however, the reanalysis results largely exceed the observational average at the end of the time series (Fig. 14b). The velocity from M2 position decreases after 2007 and reaches minimum values in 2010, suggesting a condition of slower coastal currents during the polynya event.

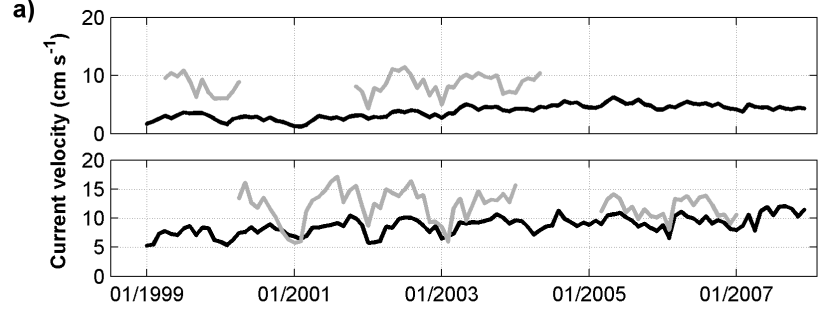

b)

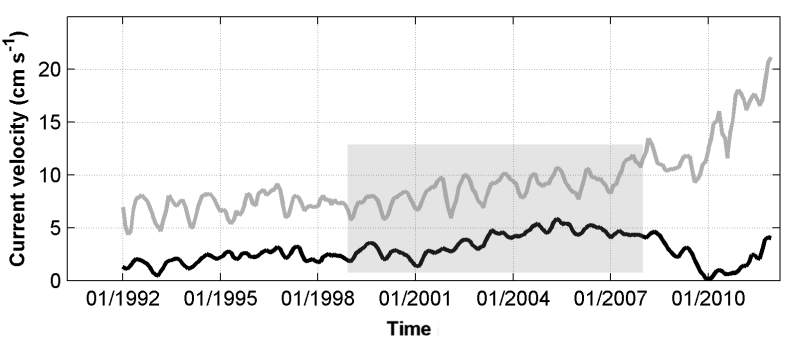

Figure 14. (a) Comparison between monthly time series of current meter (gray) and the ECCO2 (black) velocity $\left(\mathrm{cm} \mathrm{s}^{-1}\right.$ ) at $\sim 3100 \mathrm{~m}$ based on the M2 position (upper panel) and at $\sim 4580 \mathrm{~m}$ based on the M3 position (bottom panel; see mooring positions in Fig. 1). (b) Monthly ECCO2 time series of current velocity $\left(\mathrm{cm} \mathrm{s}^{-1}\right)$ at the M2 position (black line) and the M3 position (gray line) for the period 1992-2011. Both time series are filtered using a 3-month moving average. The boxes highlight the period shown in (a).

\subsubsection{Case study III: Prime Meridian/Weddell Sea sector}

Also within the Weddell Sea sector is the presence of a mooring array along the Prime Meridian that was evaluated by Klatt et al. (2005), which is hereafter referred to as K05 (case study III). At the M233 location, which is immersed in the Antarctic Coastal Current, the reanalysis absolute values are generally lower than suggested by the observations; the data are only similar during the weaker phases (December-January) of the observational data (Fig. 15a). After 2007, the abrupt increase in the velocity from the ECCO2 output leads to mean values of $-12.7 \pm 1.5 \mathrm{~cm} \mathrm{~s}^{-1}$. This velocity is much higher than the previous average found in the ECCO2 time series $\left(-2.6 \pm 1.9 \mathrm{~cm} \mathrm{~s}^{-1}\right)$ and also from the observational mean values $\left(-4.5 \pm 2.4 \mathrm{~cm} \mathrm{~s}^{-1}\right)$. The variability pattern is well correlated at M233 $(r=0.68)$; a clear annual cycle is found in both time series. Due to increases in area (Fig. 12) and velocity (Fig. 15), the contribution of AABW transport south of $60^{\circ} \mathrm{S}$ to the cross-section volume transport (Section IV; Fig. 1) increases from approximately $38 \%$ at the beginning of the time series to approximately $80 \%$ in the latter years. Two main changes occur in AABW transport (Fig. 15b), i.e., an intensification in AABW transport in 2004 and even higher values after 2008. The average AABW transport after $2008(40 \mathrm{~Sv} \pm 23)$ is much higher than the K05 estimates $(28 \mathrm{~Sv})$ 


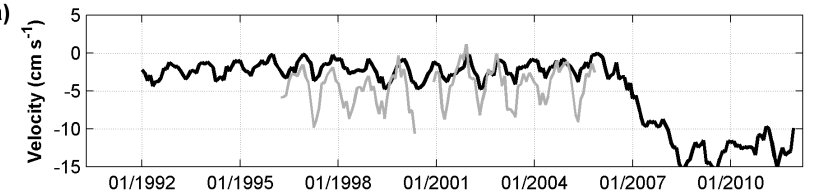

b)

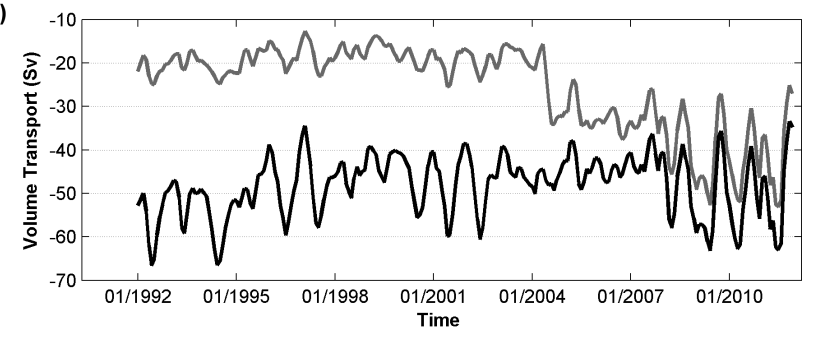

Figure 15. (a) Comparison between the monthly time series of the current meter (gray) and ECCO2 (black) zonal velocity $\left(\mathrm{cm} \mathrm{s}^{-1}\right)$ at $\sim 2000 \mathrm{~m}$ based on the M233 position (see mooring positions in Fig. 1); (b) monthly ECCO2 time series of volume transport (Sv) in Section IV considering the entire water column (black line) and only the AABW layer (gray line).

\subsubsection{Case study IV: western Weddell Sea/Weddell Sea sector}

Fahrbach et al. (2001) (hereafter referred to as F01) evaluated the export of newly formed dense bottom waters toward the northern limb of the Weddell Gyre using a mooring array at the northern tip of the Antarctic Peninsula (Section II; Fig. 1; case study IV). ECCO2-estimated AABW volume transport is also compared with the Kerr et al. (2012) model estimates, which are hereafter referred to as K12. The absolute transport values from the ECCO2 and observational data differ because of the different dense layer definitions, whereas the time series exhibit a good temporal correlation $(r=0.52$ between the ECCO2 and F01; Fig. 16a). An increase in the observed transport after 1994 (from an average value of $3.5 \pm 0.6 \mathrm{~Sv}$ prior to this year to $3.9 \pm 0.5$ afterwards) is also observed in the ECCO2 time series (from an average of $2.3 \pm 0.19 \mathrm{~Sv}$ to $8.5 \pm 3.4 \mathrm{~Sv}$ ). The volume transport estimates based on the OCCAM model evaluated by K12 also show this variability pattern; however, the absolute values are higher than the reanalysis estimates despite the same AABW layer definition. The AABW flow represented by the ECCO2 output has a well-defined seasonal cycle in which weaker flows occur in January and stronger flows occur in June (Fig. 16b). However, the months of maximum and minimum ECCO2 transport lag those determined by Fahrbach et al. (2001) by 1 month (December and May). Before 2004, the average $\mathrm{AABW}$ flow reproduced by the $\mathrm{ECCO} 2$ reanalysis at Section II $(6.7 \mathrm{~Sv})$ is very similar to the volume transport determined by Naveira Garabato et al. (2002) $(6.7 \pm 1 \mathrm{~Sv})$ and Franco et al. (2007) ( 9Sv) for WSDW exported over the South Scotia Ridge. The decrease in the reanalysis AABW volume transport after 2006 is related to a change in the local
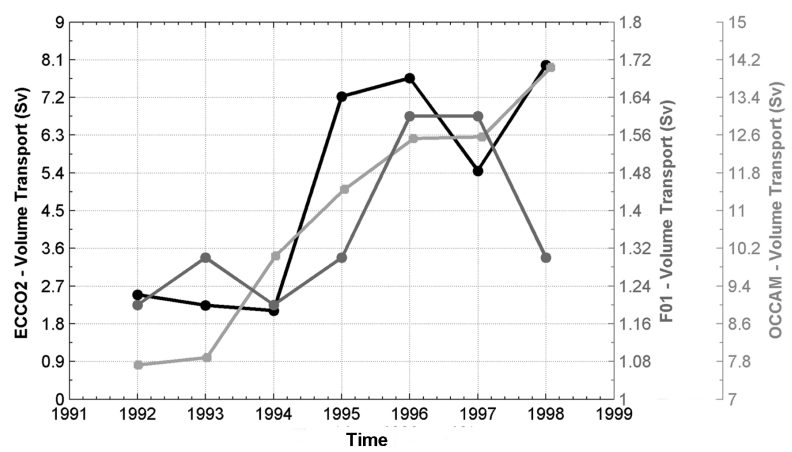

b)

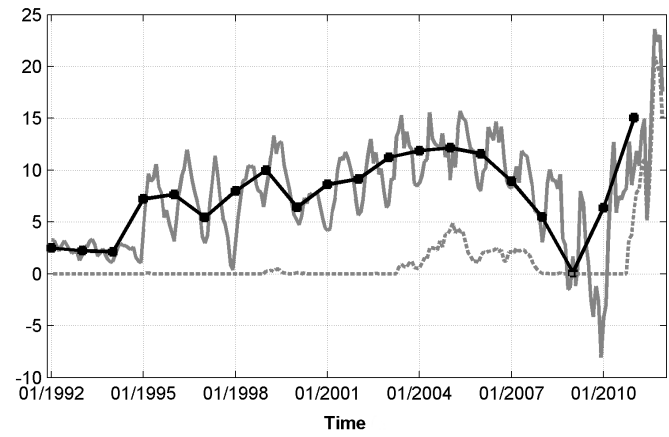

Figure 16. (a) Section II (Fig. 1) annual transport (Sv) based on the ECCO2 (black line), observational (gray line; from Fahrbach et al., 2001) and OCCAM (light gray line; from Kerr et al., 2012) data. The ECCO2 and OCCAM estimates are based on the AABW; (b) ECCO2 Section II annual (black solid line) and monthly (gray solid line) volume transport (Sv) for the AABW layer. Monthly time series considering the WSBW layer are also presented (gray dashed line).

circulation that persists until 2010. This circulation change after the polynya event is caused by the surging of currents flowing to the south along the shelf break, which dominates the northern portion of the Antarctic Peninsula shelf region in 2010 (not shown). For most of the studied period, only WSDW contributed to the AABW volume transport in the ECCO2 reanalysis (Fig. 16b). However, close to the opening of the polynya and primarily thereafter, there are episodic events of the direct injection of WSBW into the bottom layer (December 1998 to March 2000; April 2003 to September 2008; November 2010 to December 2011). During the period 2003-2008, the ECCO2 average WSBW transport (1.86 Sv) is in accordance with that reported by F01 $(1.3 \pm 0.4 \mathrm{~Sv})$. However, with the abrupt increase after 2010, the WSBW transport becomes responsible for almost all of the AABW transport. Although Section II is located north of a bottom water formation area, the origin of this dense bottom water is in southern regions. Therefore, the variability of dense water transport reported herein must be affected not only by newly formed bottom water but also by remote thermohaline and wind forcings (Fahrbach et al., 2001), including the polynya event and anomalous dense water production. 


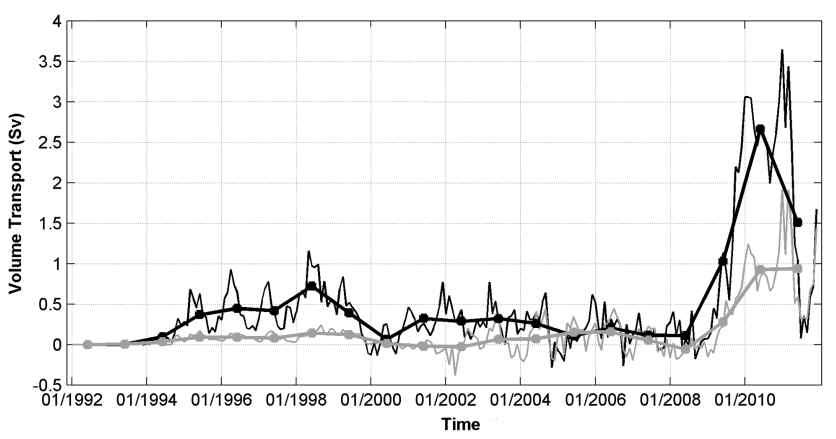

Figure 17. Annual (thick lines) and monthly (thin lines) ECCO2 volume transport in Section III of the AABW (black lines) and WSBW (gray lines).

The ventilation of the AABW to the deep Southern Ocean was evaluated by the cross-shelf break ECCO 2 bottom layer transport, which was determined within the northwestern Weddell Sea (east of the $1000 \mathrm{~m}$ isobath and from 72 to $65^{\circ} \mathrm{S}$ along the longitude $305^{\circ}$; Section III - Fig. 1). The AABW production occurs primarily in pulses (Schröder et al., 2002) that can be seen in the ECCO2 time series during three episodic periods (1994-1999, 2000-2004, and 2008-2011) (Fig. 17). The first two events exhibit an average transport of $0.25 \pm 0.25 \mathrm{~Sv}$ (positive values to the east, i.e., offshore) and coincide with the $\mathrm{AABW}$ production periods determined from the OCCAM simulation (K12). WSBW is also produced during this period, although this water mass is not detectable in the open ocean. The produced WSBW is possibly diluted via mixing because of the underrepresented volume transport that is reproduced until $2004(0.06 \pm 0.12 \mathrm{~Sv})$ relative to the $1.1 \pm 0.5 \mathrm{~Sv}$ bottom water $\left(\theta \leq-0.7^{\circ} \mathrm{C}\right)$ formation rate estimated by Huhn et al. (2008) in the same area. The intensification of AABW and WSBW production after 2008 leads to maximum values ( 3.6 and $1.9 \mathrm{~Sv}$, respectively) that exceed the values estimated by the observations.

The case studies reveal that the temporal variability of the dense water volume transport (case study IV) and current velocity (case studies II and III) determined from the reanalysis are correlated at a statistically significant level with the observationally based estimates in the regions that are most important for AABW export. Moreover, the intermittent characteristic of AABW production (case study IV) is reproduced by the reanalysis output. However, in Section I (located near the Kerguelen Plateau; case study I), the rugged bathymetry and the relatively low model resolution are possibly important factors that contribute to the difficulty in reproducing the regional variability in AABW volume transport. Moreover, the relatively short length of the observational time series must be taken into consideration in the correlation analysis results. The absolute AABW current velocity and volume transport in all of the analyzed cases are underestimated by the ECCO2 reanalysis product before 2004. There is no export of WSBW along the northern tip of the Antarctic Penin- sula (Section II; case study IV) before 2004, while its transport through the meridional Section III is considerably low, making it indistinguishable in the open ocean.

The reduced production and export of dense flow from the shelf is possibly related to the spatial resolution of the model used to create the reanalysis product, limiting the representation of coastal processes and coupled atmosphere-ocean-ice interactions. Furthermore, the diffusion scheme generally applied in $z$ level global circulation models could also be a factor. In this case, the dense water formed in the shelf region mixes horizontally and vertically when flowing down the slope (Heuzé et al., 2013); therefore, the dense signal can be lost along the downward flow as a result of mixing with intermediate waters. In the open ocean, the underestimation in the volume transport of AABW is affected by the difficulty in reproducing the export of dense waters from the Antarctic shelves (case study IV) and also by the low current velocities (case studies II and III). During more recent years, with the effect of the persistent polynya and erroneous deep water formation, AABW transport estimates greatly exceed the observationally based estimates in all of the analyzed case studies.

\subsection{Long-term AABW variability}

At the beginning of the analyzed time period (1992-1995), the four-year average AABW layer thickness reproduced by the ECCO2 reanalysis product (Fig. 18) shows a geographical distribution that is similar to (albeit slightly thinner than) the 20-year average observationally based dense layer (Fig. 18, bottom-right panel). The absence in the reanalysis of the thin dense layer seen in observations at the eastern part of the B\&A sector and the northern Ross Sea sector is related to the temperature overestimation. A retreat of the dense deep layer in the B\&A and Ross Sea sectors with time can be clearly seen in the AABW thickness. By the period 2004-2007, the AABW from the Ross Sea and B\&A sectors is restricted to the core of the Ross Gyre. A contraction of the AABW layer from the 1980 s to the 2000s was recently reported by Purkey and Johnson (2012), who noted that the Australian-Antarctic and Amundsen-Bellingshausen basins present the highest isopycnal deepening rates $\left(-13.2 \pm 6.7 \mathrm{~m} \mathrm{yr}^{-1}\right.$ and $-11.4 \pm 2.9 \mathrm{~m} \mathrm{yr}^{-1}$, respectively). A volume decrease of dense waters is also reported by Azaneu et al. (2013), who showed a $-8.06 \pm 0.38 \mathrm{~m} \mathrm{yr}^{-1}$ average AABW upper limit rate of change for the period 1958-2010. Despite the substantial retreat of the AABW layer in the ECCO2 output during the period 1992-2004, the average deepening rate of the $\mathrm{AABW}$ isopycnal from the reanalysis output $\left(-3.06 \pm 1.81 \mathrm{~m} \mathrm{yr}^{-1}\right)$ is smaller than the observational estimates determined by Purkey and Johnson (2012) and Azaneu et al. (2013). The consequences of deep convection and dense bottom water injection in the Weddell Sea during the 


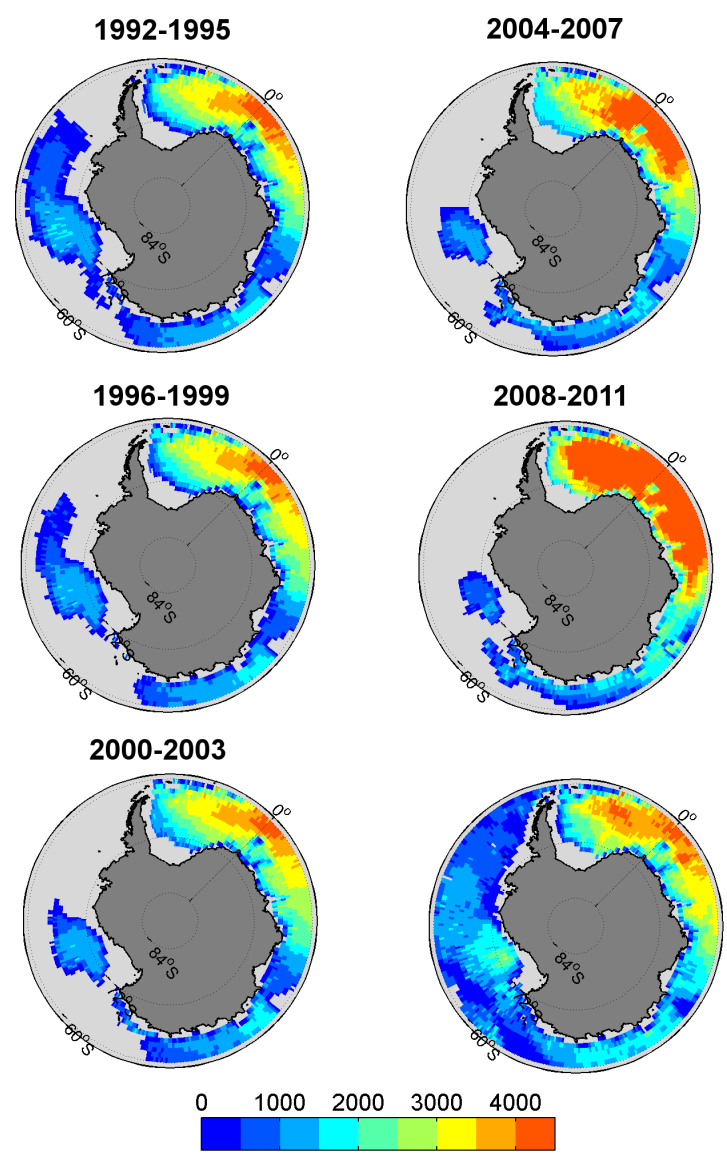

Figure 18. Four-year averages of the AABW layer thickness (m) based on the ECCO2 data for the period 1992-2010. The bottomright panel shows the 20-year average AABW layer thickness based on observational data.

polynya period are observed by the overestimation of the AABW layer thickness in the 2004-2011 average.

The temporal trends based on the regional AABW annual time series exhibit different rates of change for each Southern Ocean sector (Table 2). During the period prior to the opening of the polynya (1992-2004), all sectors experience warming, freshening, and density decreases except for the Weddell Sea sector. This region warms until $2000\left(0.0028^{\circ} \mathrm{C} \mathrm{yr}^{-1}\right)$ and then begins to become colder and fresher. Prior to a deep convection event and opening of the polynya, the vertical transport of oceanic heat vertically melts the sea ice and causes a decrease in the sea ice concentration and thickness (Martin et al., 2013). Thus, the decrease in the sea ice concentration and thickness observed ca. 2000 is potentially caused by oceanic heat in the Weddell Sea, which leads to an early cooling in the region.

The variability pattern of warming, freshening, and lightening of dense waters reproduced in most of the ocean sectors during the period 1992-2004 agrees with several observational studies (e.g., Fahrbach et al., 2004; Rintoul, 2007; Aoki et al., 2005; Purkey and Johnson, 2013). Azaneu et al. (2013) estimated an AABW average temperature, salinity, and density trend of $0.0015^{\circ} \mathrm{C} \mathrm{yr}^{-1},-0.0002 \mathrm{yr}^{-1}$, and $-0.0005 \mathrm{~kg} \mathrm{~m}^{-3} \mathrm{yr}^{-1}$ (1958-2011), although freshening is not a clear pattern throughout the Southern Ocean. The analogous average rates for the Southern Ocean sectors (i.e., $0.0023{ }^{\circ} \mathrm{C} \mathrm{yr}^{-1},-0.0002 \mathrm{yr}^{-1}$, and $-0.0007 \mathrm{~kg} \mathrm{~m}^{-3} \mathrm{yr}^{-1}$ for temperature, salinity, and density, respectively), as determined with the ECCO2 output (considering the period 1992-2004), are consistent with those found by Azaneu et al. (2013). The ECCO2 product is based on the assimilation of a large number of observational data throughout the model simulation. Therefore, in addition to interannual variability, we expect that the reanalysis should be capable of representing the observed low frequency variability. However, it is most likely that in ECCO2, the trends found are a consequence of a "natural" drift of the model. The representation of a reduced export of dense waters from the shelf and the low current velocities contributed to a longer residence period of AABW within the deep basins of the Southern Ocean. A longer residence period can enhance the mixing with the warmer CDW, which can produce the observed warming trend and the loss of the dense water signal with time. A similar process is suggested to be occurring in the real ocean due to the possible recent decrease in dense water production (Azaneu et al., 2013). In the case of ECCO2, however, the process is a consequence of its inability to properly reproduce the dense water production and ocean-ice interactions rather than a representation of a real climate trend. When the entire period is considered (i.e., 1992-2011), the anomalous production of dense waters produces a cooling trend; this trend is most evident in the Indian $\left(-0.0078^{\circ} \mathrm{C} \mathrm{yr}^{-1}\right)$ and Weddell Sea $\left(-0.0283{ }^{\circ} \mathrm{C} \mathrm{yr}^{-1}\right)$ sectors, which is directly influenced by the polynya surging. Four of the models analyzed by Heuzé et al. (2013) also exhibited bottom waters that were warmer than the real ocean and a decreasing temperature trend; however, the rate of change $\left(\sim-0.0015^{\circ} \mathrm{C} \mathrm{yr}^{-1}\right)$ found in their study is lower than those suggested by the $\mathrm{ECCO} 2$ reanalysis product.

\section{Discussion and conclusions}

The assessment of the ECCO2 output shows substantial changes in the hydrographic conditions in the simulated years, such as a warming of dense waters in the Southern Ocean (Table 2) and a retreating of the AABW layer in the B\&A and Ross Sea sectors (Fig. 18). However, the most striking modification observed is the appearance of a dense water plume in the Weddell Sea sector due to deep ocean convection. This feature is related to the opening of an oceanic polynya that is clearly visible after 2005 and is located near the center of the Weddell Gyre (Fig. 4a). This phenomenon contributes to the unrealistic representation of the Southern Ocean hydrographic properties primarily after 2004. 
Table 2. Linear fits of the annual regional AABW time series based on the ECCO2 output ${ }^{\mathrm{a}}$.

\begin{tabular}{llrr}
\hline \multirow{2}{*}{ Southern Ocean hydrographic sector } & \multicolumn{2}{c}{ Trend ${\mathrm{in} \mathrm{yr}^{-1}}^{-1}$} \\
& Hydrographic property & $1992-2004$ & $1992-2011$ \\
\hline Bellingshausen and Amundsen & $\theta\left({ }^{\circ} \mathrm{C}\right)$ & $\mathbf{0 . 0 0 4 1}$ & - \\
& $S$ & $-\mathbf{0 . 0 0 0 1}$ & - \\
& $\gamma^{\mathrm{n}}\left(\mathrm{kg} \mathrm{m}^{-3}\right)$ & $-\mathbf{0 . 0 0 0 6}$ & - \\
\hline Ross Sea & $\theta\left({ }^{\circ} \mathrm{C}\right)$ & $\mathbf{0 . 0 0 2 9}$ & $-\mathbf{0 . 0 0 0 2}$ \\
& $S$ & 0.0000 & $-\mathbf{0 . 0 0 0 3}$ \\
& $\gamma^{\mathrm{n}}\left(\mathrm{kg} \mathrm{m}^{-3}\right)$ & $-\mathbf{0 . 0 0 0 6}$ & $-\mathbf{0 . 0 0 0 5}$ \\
\hline Western Pacific & $\theta\left({ }^{\circ} \mathrm{C}\right)$ & $\mathbf{0 . 0 0 4 8}$ & $\mathbf{0 . 0 0 1 6}$ \\
& $S$ & -0.0001 & $-\mathbf{0 . 0 0 0 2}$ \\
& $\gamma^{\mathrm{n}}\left(\mathrm{kg} \mathrm{m}^{-3}\right)$ & $-\mathbf{0 . 0 0 1 0}$ & $-\mathbf{0 . 0 0 0 6}$ \\
\hline Indian & $\theta\left({ }^{\circ} \mathrm{C}\right)$ & $\mathbf{0 . 0 0 1 9}$ & $-\mathbf{0 . 0 0 7 8}$ \\
& $S$ & $-\mathbf{0 . 0 0 0 4}$ & $-\mathbf{0 . 0 0 0 7}$ \\
& $\gamma^{\mathrm{n}}\left(\mathrm{kg} \mathrm{m}^{-3}\right)$ & $-\mathbf{0 . 0 0 0 9}$ & $\mathbf{0 . 0 0 0 6}$ \\
\hline Weddell Sea & $\theta\left({ }^{\circ} \mathrm{C}\right)$ & -0.0020 & $-\mathbf{0 . 0 2 8 3}$ \\
& $S$ & $-\mathbf{0 . 0 0 0 4}$ & $-\mathbf{0 . 0 0 1 0}$ \\
& $\gamma^{\mathrm{n}}\left(\mathrm{kg} \mathrm{m}^{-3}\right)$ & $-\mathbf{0 . 0 0 0 4}$ & $\mathbf{0 . 0 0 4 5}$ \\
\hline
\end{tabular}

${ }^{a}$ Bold font indicates a statistically significant trend $(P \leq 0.05)$.

Before 2004, the ECCO2 reanalysis is able to grossly represent the main Southern Ocean oceanographic features, including the dense waters over the shelf (Figs. 5-7). The water column structure and the AABW upper limit are consistent between the reanalysis and observations within the Weddell Sea (Figs. 9-11 and 18). Moreover, estimates of the area occupied by the dense layer based on the ECCO 2 product are underestimated by less than $6 \%$ compared with the observational estimates (Figs. 12). The current velocity of deep waters near the Endurance Ridge (case study II) and at the Prime Meridian (case study III) and AABW transport east of the Antarctic Peninsula (case study IV) are well correlated with the observations.

Despite these agreements, the ECCO2 output does not agree well with respect to the AABW layer thickness and transport variability out of the Weddell Sea (Figs. 8 and 12). Moreover, surface waters around the Southern Ocean are generally depicted as being saltier and denser than suggested by the observations. The bottom layer is warmer and less dense than expected; the densest bottom water variety is lacking in the reanalysis data (Figs. 5, 7, 9-11). Furthermore, the estimated AABW volume transport and absolute velocity values are underestimated in all cases (Figs. 13-17) until the polynya event occurs. In addition, there is no export of WSBW through Section II at the northern tip of the Antarctic Peninsula before 2004 (case study IV). The misrepresentation of the surface layer is possibly the consequence of an inadequate representation of the complex processes that occur at the ocean-ice-atmosphere interface. The overestimation of the sea ice concentration in winter requires intense sea ice formation and subsequent brine rejection, which likely pro- motes high salinity surface waters. The underestimation of AABW transport and the presence of warm and less dense waters are possibly the consequence of the spatial resolution of the model, which limits the representation of coastal processes, and the diffusion scheme used in the model. Considering that the flow exported from the continental shelf is already underrepresented, the dense and cold signal is diluted during its downward flow due to vertical and horizontal mixing. Consequently, AABW transport in the open ocean is affected by the limited export of dense waters and also by the low current velocities.

An important feature noted in the reanalysis output is the reproduction of WSBW transport through the meridional Section III (northwestern Weddell Sea; case study IV) even before 2004. Although also considerably lower than suggested by the observations, this flow represents the ventilation of the Weddell Sea bottom waters with the newly formed dense waters. None of the 15 general circulation models analyzed by Heuzé et al. (2013) are capable of reproducing the spilling and sinking of dense waters from the shelf. Half of the models use open ocean deep convection as the main mechanism to create deep water. In the ECCO2 reanalysis, this mechanism surges only after 2004; thereafter, this mechanism has the larger effect on the transport of AABW and the hydrographic properties not only in the Weddell Sea but also in remote areas, e.g., in Section I of the Indian sector.

Deep convection generally begins with a decrease in stability within the water column, which can be caused by surface water buoyancy loss or an increase in the buoyancy of deep waters. Several factors, such as increased heat loss to the atmosphere, changes in surface fluxes, and brine rejec- 
tion from ice formation, can trigger the process and allow for the mixture of cold surface waters with saltier intermediate waters (Martin et al., 2013). In addition, some aspects can precondition this process, e.g., the strong cyclonic gyre that is present in the Weddell Sea, which is naturally associated with upwelling of the pycnocline, and also the interaction of the circulation with the seabed topography near the Maud Rise (Gordon and Huber, 1990).

Martin et al. (2013) evaluated two experiments with the Kiel Climate Model and found a quasi-periodic occurrence of deep convection in the Atlantic sector of the Southern Ocean. According to the authors, the main trigger for deep convection in these experiments was the heat accumulation at intermediate depths. The inflow of warm NADW into the Atlantic-Indian Basin is the primary heat source, which is trapped in the gyre circulation by the westward return flow to the south of the Weddell Gyre. Heat then accumulates at a depth of approximately $1500 \mathrm{~m}$ during periods without convection and subsequently spreads in depth, acting to warm the entire water column below $100 \mathrm{~m}$. Sea ice compactness regulates the occurrence of deep convection; however, brine rejection is not essential for triggering the mixing process. The ECCO2 output comprises a short period of time that includes only one deep convection event, which limits the understanding of this process. However, the heat accumulation at intermediate depths described by Martin et al. (2013) is not evident in the ECCO2 output (see the Supplement, Fig. S4). Although the heat accumulation is absent, the warming of deep waters and cooling at intermediate depths are both present prior to the polynya event. The cooling of WDW $\left(-0.0374{ }^{\circ} \mathrm{C} \mathrm{yr}^{-1}\right)$ in ECCO 2 was also identified by Dotto et al. (2014) within the Weddell Sea, which reinforces the idea that the AABW warming is the consequence of the weak export and mixing of less dense waters.

We believe that the difficulty in reproducing the export of dense waters along the continental slope in the reanalysis, which produces less dense deep and bottom layers, results in a less stratified Southern Ocean, as suggested by de Lavergne et al. (2014). The warming trend of AABW and the too strong seasonality of sea ice are also important contributors to decreases in the stability of the water column and create favorable conditions for the initiation of deep convection. Thus, warmer waters in the deep and bottom layers and saltier waters at the surface should be the determinant factors for convective mixing and the homogenization of the water column in the ECCO2 reanalysis. The heat transported to the surface melts the sea ice and hinders the formation of new ice, leading to the opening and the maintenance of the large oceanic polynya after 2004. Deep waters become colder due to heat loss at the surface, leading to the production of dense waters at deeper levels (typically below $2000 \mathrm{~m}$ ) in the Weddell Sea after 2004.

Deep convection affects not only the hydrographic properties of the water masses but also the velocity and transport of AABW around most of the Southern Ocean. Two major changes are observed in the transport of dense waters after the opening of the polynya (Fig. 15). The first change occurs ca. 2004 due to the large volume of dense water being produced; the second change occurs primarily after 2007 as a consequence of an increase in ocean current velocities. With the initiation of deep convection, it appears that the reanalysis data more closely represent the real ocean, reproducing dense water velocities, transport and export of WSBW that mimic the observations. However, primarily after 2007, WSBW is widely produced by deep convection and the current velocities increase, leading to estimates of AABW transport that largely exceed the observations in the analyzed cases. Deep convection can also contribute to increased transport estimates due to its effect on oceanic pressure gradients. This mechanism causes a rise in the isopycnals south of the ACC and an increase in the ACC strength. Consequently, the Weddell Gyre (Martin et al., 2013) and the current velocities are also intensified. Moreover, the sea ice retreat enables a more direct effect of wind stress over the ocean, which may have also intensified the Weddell Gyre's barotropic circulation depicted in the reanalysis data and consequently contributed to convective mixing. Moreover, the transport by ocean currents is enhanced, which facilitates the spreading of the dense AABW plume.

The results reveal that the ECCO2 reanalysis product requires extensive improvements regarding the representation of AABW in the Southern Ocean. Based on the careful comparisons performed, reanalysis output from the 1992-2004 period can be suitable for studies focused on the AABW climatological distribution and velocity/transport high-frequency variability within the Weddell Sea. Lowfrequency AABW variability is directly influenced by model drift and should not be investigated using the reanalysis output. During this period, the misrepresentation of the bottom layer in the ECCO2 product is comparable with the performance of other models (Heuzé et al., 2013), which demonstrates that dense water representation is a limiting factor in hydrographic modeling. Most of these models also use deep convection as an important mechanism for dense water formation. However, in the ECCO 2 reanalysis product, a combination of factors leads to an unrealistic scenario in the more recent years, i.e., the currents are much stronger than expected and the Weddell Sea is flooded with very dense waters that occupy nearly the entire water column. Therefore, the use of data from the latter period (2005-2011) is not advisable for any purpose.

These findings reinforce the need for an accurate representation of sea ice coverage and variability and of the processes occurring over both shelves and slopes for conducting adequate simulations of deep Southern Ocean hydrography. Improvements in the limitations related to model resolution, ice shelf representation, and sub-grid physical parameterizations, e.g., vertical mixing, convective processes, downslope flow, and sea ice growth, must be considered for optimal results. Despite the deficiencies of the ECCO2 output evalu- 
ated in this study, it is important to highlight the improved performance of this reanalysis in reproducing the AABW properties (for the period 1992-2004) in comparison with other commonly used modeled data, such as OCCAM and ORCA025 (Renner et al., 2009; K12).

The ECCO2 reanalysis data set is an ongoing project, and several efforts have been made to improve key points, e.g., ice shelf representation. Recent studies have applied regional ECCO2 configurations modified to include explicit representations of ice shelves to investigate the process in the ocean and ice interface (Heimbach and Losch, 2012; Schodlok et al., 2012; Xu et al., 2012). Moreover, the centerpiece of the $\mathrm{ECCO} 2$ is the application of an adjoint-method optimization of the global eddying configuration, which would enable a much larger number of control variables than the Green's function method. The adjoint-method optimization method has already been proven to be valuable (e.g., Mazloff et al., 2010; Ito et al., 2010), and its application both globally and for a longer time period than the actual SOSE (Southern Ocean State Estimation) regional solution would produce a substantial improvement.

Finally, long-term observational studies in important regions of the AABW export must be conducted. The focus of these studies should be extended beyond the Weddell and Ross Sea regions to less explored (but also important) areas, such as the Kerguelen Plateau region, which has shown the poorest representation of AABW variability. In addition, the lack of observations for winter months affects the quality of reanalysis assimilation and limits the assessment of these data sets and models. The use of new technologies for sampling during wintertime under seasonal ice cover, such as Argo, Deep Argo floats, sea gliders, and ice-tethered buoys, and the use of marine mammals as platforms for data collection in shelf and shelf break regions should be encouraged.

\section{The Supplement related to this article is available online at doi:10.5194/os-11-923-2014-supplement.}

Acknowledgements. This study is a contribution to the activities of the Brazilian High Latitudes Oceanography Group (GOAL) and the Brazilian National Institute of Science and Technology of Cryosphere (INCT-CRIOSFERA; 573720/2008-8). GOAL has been funded by the Brazilian Antarctic Program (PROANTAR) through the Brazilian Ministry of the Environment (MMA), the Brazilian Ministry of Science, Technology and Innovation (MCTI), and the Council for Research and Scientific Development of Brazil (CNPq; 550370/2002-1; 520189/2006-0; 556848/2009-8; 405869/2013-4). M. Azaneu and R. Kerr acknowledge financial support from the CAPES Foundation and FAPERGS. We thank Y. Fukamachi for providing data on the AABW volume transport for the eastern Kerguelen Plateau and also the Estimating the Circulation and Climate of the Ocean - Phase II (ECCO2) working group for producing and making their reanalysis output freely available.
Edited by: M. Hecht

\section{References}

Adcroft, A., Dutkiewicz, S., Ferreira, D., Heimbach, P., Jahn, O., and Maze, G.: Mitgcm user manual, Tech. rep., MIT Department of Earth, Atmospheric and Planetary Sciences, 2012.

Aoki, S., Rintoul, S. R., Ushio, S., Watanabe, S., and Bindoff, N. L.: Freshening of the Adélie Land Bottom Water near $140^{\circ} \mathrm{E}$, Geophys. Res. Lett., 32, L23601, doi:10.1029/2005GL024246, 2005.

Azaneu, M., Kerr, R., Mata, M. M., and Garcia, C. A. E.: Trends in the deep Southern Ocean (1958-2010): implications for Antarctic Bottom Water properties and volume export, J. Geophys. Res., 118, 4213-4227, doi:10.1002/jgrc.20303, 2013.

Boyer, T. P., Antonov, J. I., Baranova, O. K., Garcia, H. E., Johnson, D. R., Locarnini, R. A., Mishonov, A. V., O’Brien, T. D., Seidov, D., Smolyar, I. V., and Zweng, M. M.: World Ocean Database 2009, NOAA Atlas NESDIS, 66, edited by: Levitus, S., DVD, US Gov. Printing Office, Washington, DC, 2009.

Carmack, E. C. and Foster, T. D.: On the flow of water out of the Weddell Sea, Deep-Sea Res., 22, 711-724, 1975.

Cavalieri, D. J. and Parkinson, C. L.: Antarctic sea ice variability and trends, 1979-2006, J. Geophys. Res., 113, C07004, doi:10.1029/2007JC004564, 2008.

Cavalieri, D. J., Parkinson, C., Gloersen, P., and Zwally, H. J.: Sea ice concentrations from Nimbus-7 SMMR and DMSP SSM/I passive microwave data, January 1979-June 2006, National Snow and Ice Data Center, Boulder, Colorado USA, digital media, 1996, updated 2006.

Condron, A., Winsor, P., Hill, C., and Menemenlis, D.: Simulated response of the Arctic freshwater budget to extreme NAO wind forcing, J. Climate, 22, 2422-2437, 2009.

Curry, J. A. and Webster, P. J.: Sea ice, snow, and glaciers, in: Thermodynamics of Atmospheres and Oceans, 65, chap. 10, edited by: Curry, J. A. and Webster, P. J., 1-471, 1999.

de Lavergne, C., Palter, J. B., Galbraith, E. D., Bernardello, R., and Marinov, I.: Cessation of deep convection in the open Southern Ocean under anthropogenic climate change, Nature Climate Change, 4, 278-282, 2014.

Dotto, T. S., Kerr, R., Mata, M. M., Azaneu, M., Wainer, I., Fahrbach, E., and Rohardt, G.: Assessment of the structure and variability of Weddell Sea water masses in distinct ocean reanalysis products, Ocean Sci., 10, 523-546, doi:10.5194/os-10-5232014, 2014.

Fahrbach, E., Harms, S., Rohardt, G., Schröder, M., and Woodgate, R. A.: Flow of bottom water in the northwestern Weddell Sea, J. Geophys. Res., 106, 2761-2778, 2001.

Fahrbach, E., Hoppema, M., Rohardt, G., Schröder, M., and Wisotzki, A.: Decadal-scale variations of water mass properties in the deep Weddell Sea, Ocean Dynam., 54, 77-91, 2004.

Fahrbach, E., Hoppema, M., Rohardt, G., Boebel, O., Klatt, O., and Wisotzki, A.: Warming of deep and abyssal water masses along the Greenwich meridian on decadal time scales: the Weddell gyre as a heat buffer, Deep-Sea Res. Pt. II, 58, 2509-2523, 2011.

Foldvik, A., Gammelsröd, T., and Törresen, T.: Circulation and water masses on the southern Weddell Sea shelf, Antarct. Res. Ser., 43, 5-20, 1985. 
Foldvik, A., Gammelsrod, T., Osterhus, S., Fahrbach, E., Rohardt, G., Schröder, M., Nicholls, K. W., Padman, L., and Woodgate, R. A.: Ice shelf water overflow and bottom water formation in the southern Weddell Sea, J. Phys. Oceanogr., 109, C02015, doi:10.1029/2003JC002008, 2004.

Franco, B., Mata, M. M., Piola, A. R., and Garcia, C. A. E.: Northwestern Weddell Sea deep outflow into the Scotia Sea during the austral summers of 2000 and 2001 estimated by inverse methods, Deep-Sea Res. Pt. I, 54, 1815-1840, 2007.

Fukamachi, Y., Rintoul, S. R., Church, J. A., Aoki, S., Sokolov, S., Rosenberg, M. A., and Wakatsuchi, M.: Strong export of Antarctic BottomWater east of the Kerguelen plateau, Nat. Geosci., 3, 327-331, 2010.

Gill, A. E.: Circulation and bottom water production in the Weddell Sea, Deep-Sea Res., 20, 111-140, 1973.

Gille, S. T.: Warming of the Southern Ocean since the 1950s, Science, 295, 1275-1277, 2002.

Gordon, A. L.: Deep Antarctic convection west of Maud Rise, J. Phys. Oceanogr., 8, 600-612, 1977.

Gordon, A. L. and Huber, B.: Southern Ocean winter mixed layer, J. Geophys. Res., 95, 11655-11672, doi:10.1029/JC095iC07p11655, 1990.

Gordon, A. L., Huber, B. A., Mckee, D., and Visbeck, M.: A seasonal cycle in the export of bottom water from the Weddell Sea, Nat. Geosci., 3, 551-556, 2010.

Heimbach, P. and Losch, M.: Adjoint sensitivities of sub-ice-shelf melt rates to ocean circulation under the Pine Island Ice Shelf, West Antarctica, Ann. Glaciol., 53, 59-69, 2012.

Hellmer, H. H., Huhn, O., Gomis, D., and Timmermann, R.: On the freshening of the northwestern Weddell Sea continental shelf, Ocean Sci., 7, 305-316, doi:10.5194/os-7-305-2011, 2011.

Heuzé, C., Heywood, K. J., Stevens, D. P., and Ridley, J. K.: Southern Ocean bottom water characteristics in CMIP5 models, Geophys. Res. Lett., 40, 1409-1414, 2013.

Huhn, O., Hellmer, H. H., Rhein, M., Rodehacke, C., Roether, W., Schodlok, M. P., and Schröder, M.: Evidence of deep- and bottom-water formation in the western Weddell Sea, Deep-Sea Res. Pt. II, 55, 1098-1116, 2008.

Huhn, O, Rhein, M, Hoppema, M and van Heuven, S.: Decline of deep and bottom water ventilation and slowing down of anthropogenic carbon storage in the Weddell Sea, 1984-2011, DeepSea Res. Pt. I, 76, 66-84, doi:10.1016/j.dsr.2013.01.005, 2013.

Ito, T., Woloszyn, M., and Mazloff, M.: Anthropogenic carbon dioxide transport in the Southern Ocean driven by Ekman flow, Nature, 463, 80-83, 2010.

Jackett, D. R. and McDougall, T. J.: A neutral density variable for the world's ocean, J. Phys. Oceanogr., 27, 237-263, 1997.

Jacobs, S. S.: On the nature and significance of the Antarctic Slope Front, Mar. Chem., 35, 9-24, 1991.

Jacobs, S. S.: Bottom water production and its links with the thermohaline circulation, Antarct. Sci., 16, 427-437, 2004.

Jacobs, S. S. and Giulivi, C. F.: Large multidecadal salinity trends near the Pacific-Antarctic continental margin, J. Climate, 23, 4508-4524, doi:10.1175/2010JCLI3284.1, 2010.

Jacobs, S. S., Giulivi, C. F., and Mele, P. A.: Freshening of the Ross Sea during the late 20th century, Science, 297, 386-389, doi:10.1126/science.1069574, 2002.
Johnson, G. C., Purkey, S. G., and Bullister, J. L.: Warming and freshening in the abyssal southeastern Indian Ocean, J. Climate, 21, 5351-5363, 2008.

Johnson, G. C.: Quantifying Antarctic Bottom Water and North Atlantic Deep Water volumes, J. Geophys. Res., 113, C05027, doi:10.1029/2007JC004477, 2008.

Kerr, R., Mata, M. M., and Garcia, C. A. E.: On the temporal variability of the Weddell Sea Deep Water Masses, Antarct. Sci., 21, 383-400, doi:10.1017/S0954102009001990, 2009.

Kerr, R., Heywood, K. J., Mata, M. M., and Garcia, C. A. E.: On the outflow of dense water from the Weddell and Ross Seas in OCCAM model, Ocean Sci., 8, 369-388, doi:10.5194/os-8-3692012, 2012.

Killworth, P. D.: Deep convection in the world ocean, Rev. Geophys. Space Ge., 21, 1-26, 1983.

Klatt, O., Fahrbach, E., Hoppema, M., and Rohardt, G.: The transport of the Weddell Gyre across the Prime Meridian, Deep-Sea Res. Pt. II, 52, 513-528, 2005.

Lee, T., Awaji, T., Balmaseda, M., Ferry, N., Fujii, Y., Fukumori, I., Giese, B., Heimbach, P., Köhl, A., Masina, S., Remy, E., Rosati, A., Schodlok, M., Stammer, D., and Weaver, A.: Consistency and fidelity of Indonesian-throughflow total volume transport estimated by 14 ocean data assimilation products, Dynam. Atmos. Oceans, 50, 201-223, doi:10.1016/j.dynatmoce.2009.12.004, 2010.

Lumpkin, R. and Speer, K.: Global ocean meridional overturning, J. Phys. Oceanogr., 37, 2550-2562, 2007.

Marshall, J., Adcroft, A., Hill, C., Perelman, L., and Heisey, C.: A finite-volume, incompressible Navier-Stokes model for studies of the ocean on parallel computers, J. Geophys. Res., 102, 5753-5766, 1997.

Martin, T., Wonsun, P., and Latif, M.: Multi-Centennial Variability Controlled by Southern Ocean Convection in the Kiel Climate Model Climate Dynamics, 40 pp., 2005-2022, doi:10.1007/s00382-012-1586-7, 2013.

Maximenko, N. and Niiler, P.: Hybrid decade-mean global sea level with mesoscale resolution, in: Recent Advances in Marine Science and Technology, edited by: Saxena, N., PACON International, Honolulu, 55-59, 2005.

Mazloff, M. R., Heimbach, P., and Wunsch, C.: An eddy-permitting Southern Ocean state estimate, J. Phys. Oceanogr., 40, 880-899, 2010.

McKee, D. C., Yuan, X., Gordon, A. L., Huber, B. A., and Dong, Z.: Climate impact on interannual variability of Weddell Sea Bottom Water, J. Geophys. Res., 116, C05020, doi:10.1029/2010JC006484, 2011.

Menemenlis, D., Fukumori, I., and Lee, T.: Using Green's functions to calibrate an ocean general circulation model, Mon. Weather Rev., 133, 1224-1240, 2005.

Menemenlis, D., Campin, J. M., Heimbach, P., Hill, C., Lee, T., Schodlok, M., and Zhang, H.: ECCO2: high resolution global ocean and sea ice data synthesis, Mercator Ocean Quarterly Newsletter, 31, 13-21, 2008.

Meredith, M. P., Locarnini, R. A., Van Scoy, K. A.,Watson, A. J., Heywood, K. J., and King, B. A.: On the sources of Weddell Gyre Antarctic Bottom Water, J. Geophys. Res., 105, 1093-1104, 2000. 
Morales Maqueda, M. A., Willmott, A. J., and Biggs, N. R. T.: Polynya dynamics: A review of observations and modeling, Rev. Geophys., 42, RG1004, doi:10.1029/2002RG000116, 2004.

Muench, R. D. and Hellmer, H. H.: The international DOVETAIL program, Deep Sea Res.-Pt. II, 49, 4711-4714, 2002.

Naveira Garabato, A. C., McDonagh, E. L., Stevens, D. P., Heywood, K. J., and Sanders, R. J.: On the export of Antarctic Bottom Water from the Weddell Sea, Deep-Sea Res., 49, 4715-4742, 2002.

Nguyen, A. T., Menemenlis, D., and Kwok, R.: Improved modeling of the Arctic halocline with a subgrid-scale brine rejection parameterization, J. Geophys. Res., 114, C11014, doi:10.1029/2008JC005121, 2009.

Nicholls, K. W., Østerhus, S., Makinson, K., Gammelsrød, T., and Fahrbach, E.: Ice-ocean processes over the continental shelf of the southern Weddell Sea, Antarctica: a review, Rev. Geophys., 47, 1-23, doi:10.1029/2007RG000250, 2009.

Onogi, K., Tsutsui, J., Koide, H., Sakamoto, M., Kobayashi, S., Hatsushika, H., Matsumoto, T., Yamazaki, N., Kamahori, H., Takahashi, K., Kadokura, S., Wada, K., Kato, K., Oyama, R., Ose, T., Mannoji, N., and Taira, R.: The JRA-25 reanalysis, J. Meteorol. Soc. Jpn., 85, 1-3, 2007.

Orsi, A. H., Nowlin, W. D., and Whitworth, T.: On the circulation and stratification of the Weddell Gyre, Deep-Sea Res. Pt. I, 40, 169-303, 1993.

Orsi, A. H., Whitworth III, T., Nowlin Jr., W. D., Whitworth, T., and Nowlin, W. D.: On the meridional extent and fronts of the Antarctic Circumpolar Current, Deep-Sea Res. Pt. I, 42, 641-673, 1995.

Orsi, A. H., Johnson, G. C., and Bullister, J. L.: Circulation, mixing and production of Antarctic Bottom Water, Prog. Oceanogr., 43, 55-109, 1999.

Parkinson, C. L. and Cavalieri, D. J.: Antarctic sea ice variability and trends, 1979-2010, The Cryosphere, 6, 871-880, doi:10.5194/tc-6-871-2012, 2012.

Purkey, S. G. and Johnson, G. C.: Global contraction of Antarctic Bottom Water between the 1980s and 2000s, J. Climate, 25, 5830-5844, 2012.

Purkey, S. G. and Johnson, G. C.: Antarctic Bottom Water Warming and Freshening: Contributions to Sea Level Rise, Ocean Freshwater Budgets, and Global Heat Gain, J. Climate, 26, 6105-6122, doi:10.1175/JCLI-D-12-00834.1, 2013.

Rahmstorf, S.: Thermohaline ocean circulation, in: Encyclopedia of Quaternary Sciences, edited by: Elias, S. A., Elsevier, Amsterdam, 739-750, 2006.

Renner, A. H. H., Heywood, K. J., and Thorpe, S. E.: Validation of three global ocean models in the Weddell Sea, Ocean Model., 30, 1-15, 2009.

Rignot, E., Fenty, I., Menemenlis, D., and Xu, Y.: Spreading of warm ocean waters around Greenland as a possible cause for glacier acceleration, Ann. Glaciol., 53, 257-266, 2012.

Rintoul, S. R.: On the origin and infuence of Adelie Land Bottom Water, in: Ocean, Ice and Atmosphere: Interactions at Antarctic Continental Margin, edited by: Jacobs, S. S. and Weiss, R., Antarctic Research Series, Vol. 75, American Geophysical Union, Washington, DC, 151-171, 1998.

Rintoul, S. R.: Rapid freshening of Antarctic Bottom Water formed in the Indian and Pacific oceans, Geophys. Res. Lett., 34, 1-5, 2007.
Rintoul, S. R. and Bullister, J. L.: A late winter hydrographic section from Tasmania to Antarctica, Deep-Sea Res. Pt. I, 46, 1417-1454, 1999.

Rintoul, S. R., Sparrow, M., Meredith, M. P., Wadley, V., Speer, K., Hofmann, E., Summerhayes, C., Urban, E., Bellerby, R., Ackley, S., Alverson, K., Ansorge, I., Aoki, S., Azzolini, R., Beal, L., Belbeoch, M., Bergamasco, A., Biuw, M., Boehme, L., Budillon, G., Campos, L., Carlson, D., Cavanagh, R., Charpentier, E., Chul Shin, H., Coffin, M., Constable, A., Costa, D., Cronin, M., De Baar, H., De Broyer, C., De Bruin, T., De Santis, L., Butler, E., Dexter, P., Drinkwater, M., England, M., Fahrbach, E., Fanta, E., Fedak, M., Finney, K., Fischer, A., Frew, R., Garzoli, S., Gernandt, H., Gladyshev, S., Gomis, D., Gordon, A., Gunn, J., Gutt, J., Haas, C., Hall, J., Heywood, K., Hill, K., Hindell, M., Hood, M., Hoppema, M., Hosie, G., Howard, W., Joiris, C., Kaleschke, L., Kang, S. H., Kennicutt, M., Klepikov, A., Lembke-Jene, L., Lovenduski, 5 N., Lytle, V., Mathieu, P. P., Moltmann, T., Morrow, R., Muelbert, M., Murphy, E., Naganobu, M., Naveira Garabato, A., Nicol, S., O'Farrell, S., Ott, N., Piola, A., Piotrowicz, S., Proctor, R., Qiao, F., Rack, F., Ravindra, R., Ridgway, K., Rignot, E., Ryabinin, V., Sarukhanian, E., Sathyendranath, S., Schlosser, P., Schwarz, J., Smith, G., Smith, S., Southwell, C., Speich, S., Stambach, W., Stammer, D., Stansfield, K., Thiede, J., Thouvenot, E., Tilbrook, B., Wadhams, P., Wainer, I., Willmott Puig, V., Wijffels, S., Woodworth, P., Worby, T., and Wright, S.: The Southern Ocean Observing System: Initial Science and Implementation Strategy, SCAR and SCOR, 74 pp., 2012.

Robertson, R., Visbeck, M., Gordon, A. L., and Fahrbach, E.: Longterm temperature trends in the deep waters of the Weddell Sea, Deep Sea Res.-Pt. II, 49, 4791-4806, 2002.

Schodlok, M., Menemenlis, D., Rignot, E., and Studinger, M.: Sensitivity of the ice shelf ocean system to the sub-ice shelf cavity shape measured by NASA IceBridge in Pine Island Glacier, West Antarctica, Ann. Glaciol., 53, 156-162, 2012.

Schröder, M., Hellmer, H., and Absy, J. M.: On the near bottom variability in the northwestern Weddell Sea, Deep-Sea Res. Pt. II, 49, 4767-4790, doi:10.1016/S0967-0645(02)00158-3, 2002.

Shimada, K., Aoki, S., Ohshima, K. I., and Rintoul, S. R.: Influence of Ross Sea Bottom Water changes on the warming and freshening of the Antarctic Bottom Water in the AustralianAntarctic Basin, Ocean Sci., 8, 419-432, doi:10.5194/os-8-4192012, 2012.

Talley, L. D.: Closure of the global overturning circulation through the Indian, Pacific, and Southern Oceans: schematics and transports, Oceanography, 26, 80-97, 2013.

Taylor, K. L.: Summarizing multiple aspects of model performance in a single diagram, J. Geophys. Res., 106, 7183-7192, 2001.

van Sebille, E., Spence, P., Mazloff, M. R., England, M. H., Rintoul, S. R., and Saenko, O. A.: Abyssal connections of Antarctic Bottom Water in a Southern Ocean state estimate, Geophys. Res. Lett., 40, 2177-2182, doi:10.1002/grl.50483, 2013.

Volkov, D. L., Fu, L.-L., and Lee, T.: Mechanisms of the meridional heat transport in the Southern Ocean, Ocean Dynam., 60, 791-801, 2010.

Weppernig, R., Schlosser, P., Khatiwala, S., and Fairbanks, R. G.: Isotope data from ice station Weddell: implications for deep water formation in the Weddell Sea, J. Geophys. Res., 101, 25723-25739, 1996. 
Whitworth, T., Orsi, A. H., Kim, S. J., Nowlin Jr., W. D., and Locarnini, R. A.: Water masses and mixing near the Antarctic slope front, in: Ocean, Ice, and Atmosphere: Interactions at the Antarctic Continental Margin, edited by: Jacobs, S. S. and Weiss, R. F., Antarctic Research Series, Vol. 75, AGU, Washington, DC, 1-27, 1998.

Wunsch, C., Heimbach, P., Ponte, R. M., and Fukumori, I.: The global general circulation of the ocean estimated by the ECCOConsortium, Oceanography, 22, 88-103, 2009.
Wunsch, C. and Heimbach, P.: Bidecadal Thermal Changes in the Abyssal Ocean, J. Phys. Oceanogr., 44, 2013-2030, doi:10.1175/JPO-D-13-096.1, 2014.

$\mathrm{Xu}$, Y., Rignot, E., Menemenlis, D., and Koppes, M. N.: Numerical experiments on subaqueous melting of Greenland tidewater glaciers in response to ocean warming and enhanced subglacial discharge, Ann. Glaciol., 53, 229-234, 2012.

Zhang, J., Hibler, W., Steele, M., and Rothrock, D.: Arctic ice-ocean modeling with and without climate restoring, J. Phys. Oceanogr., 28, 191-217, 1998. 